\title{
Nanomaterials for the Photothermal Killing of Bacteria
}

\author{
Sibidou Yougbaré ${ }^{1,2,+}\left(\mathbb{0}\right.$, Chinmaya Mutalik ${ }^{1,+}$, Dyah Ika Krisnawati ${ }^{3}$, Heny Kristanto ${ }^{3}$, \\ Achmad Jazidie ${ }^{4,5}$, Mohammad Nuh ${ }^{6}$, Tsai-Mu Cheng $7,8, *$ (D) and Tsung-Rong Kuo ${ }^{1,9, *(1)}$ \\ 1 International Ph.D. Program in Biomedical Engineering, College of Biomedical Engineering, Taipei Medical \\ University, Taipei 11031, Taiwan; d845107003@tmu.edu.tw (S.Y.); cmutalik41@gmail.com (C.M.) \\ 2 Institut de Recherche en Sciences de la Santé (IRSS-DRCO)/Nanoro, 03 B.P 7192, \\ Ouagadougou 03, Burkina Faso \\ 3 Dharma Husada Nursing Academy, Kediri, East Java 64114, Indonesia; dyahkrisna77@gmail.com (D.I.K.); \\ direkturadhkediri@gmail.com or henykristanto1@gmail.com (H.K.) \\ 4 Department of Electrical Engineering, Institut Teknologi Sepuluh Nopember, Surabaya 60111, Indonesia; \\ rektor@unusa.ac.id \\ 5 Universitas Nahdlatul Ulama Surabaya, Surabaya 60111, Indonesia \\ 6 Department of Biomedical Engineering, Institut Teknologi Sepuluh Nopember, Surabaya 60111, Indonesia; \\ nuh@ee.its.ac.id or nuh@unusa.ac.id \\ 7 Graduate Institute of Translational Medicine, College of Medicine and Technology, Taipei Medical University, \\ Taipei 11031, Taiwan \\ 8 TMU Research Center of Cancer Translational Medicine, Taipei Medical University, Taipei 11031, Taiwan \\ 9 Graduate Institute of Nanomedicine and Medical Engineering, College of Biomedical Engineering, \\ Taipei Medical University, Taipei 11031, Taiwan \\ * Correspondence: tmcheng@tmu.edu.tw (T.-M.C.); trkuo@tmu.edu.tw (T.-R.K.) \\ $\dagger$ These authors contributed equally to this work.
}

Received: 4 May 2020; Accepted: 3 June 2020; Published: 6 June 2020

\begin{abstract}
An upsurge in the multidrug-resistant (MDR) bacterial pestilence is a global cause for concern in terms of human health. Lately, nanomaterials with photothermal effects have assisted in the efficient killing of MDR bacteria, attributable to their uncommon plasmonic, photocatalytic, and structural properties. Examinations of substantial amounts of photothermally enabled nanomaterials have shown bactericidal effects in an optimized time under near-infrared (NIR) light irradiation. In this review, we have compiled recent advances in photothermally enabled nanomaterials for antibacterial activities and their mechanisms. Photothermally enabled nanomaterials are classified into three groups, including metal-, carbon-, and polymer-based nanomaterials. Based on substantial accomplishments with photothermally enabled nanomaterials, we have inferred current trends and their prospective clinical applications.
\end{abstract}

Keywords: nanomaterial; photothermal; antibacterial activity; metal nanostructure; carbon-based nanocomposite; polymer

\section{Introduction}

Bacterial infections constitute a serious threat to public health and remain a challenge for researchers. Despite the magnitude of antimicrobial resistance, the development and approval of new antibiotics are rare nowadays [1-3]. The use of antibiotics is a common way to treat infections, but this can lead to resistant bacterial strains due to mutations [4]. This situation occurs because of inappropriate uses of antibiotics. In terms of inappropriate uses, more than $90 \%$ of antibiotics were found to have been overused or misused [5]. Some situations involving surgical acts can increase 
healthcare costs and patient sufferance, with long-lasting antibiotherapy [6]. The long-term use of antibiotherapy, however, can also cause discomfort and toxicity.

To overcome these issues, light-based treatments that utilize nanomaterials and their composites have been developed. Among these nanomaterials, photothermal therapy (PTT) presents multiple advantages, such as being minimally invasive, remotely controllable, and efficient $[7,8]$. Moreover, PTT does not cause mutations in bacteria and also has a wide antibacterial spectrum [9]. Nanomaterials used for PTT in bacterial infections can be grouped into three sections: metal nanomaterials, carbon-based nanocomposites, and polymers. Organic nanoparticles (NPs) have shown excellent biocompatibility and are cheaper [10-14]. Metal NPs possess five-times the absorption compared to organic ones, and much smaller amounts are thus needed [15]. For many reasons, such as bacterial targeting and synergistic effects when utilizing heat and other bacterial toxicities, many metal nanocomposites have been prepared and their photothermal performances have been calibrated [16-20]. Another important group of photothermal agents comprises carbon-based nanomaterials (CBNs). In this group, carbon nanotubes (CNs), graphene oxide (GO), and graphene quantum dots (GQDs) have shown great potential. In addition to the aforementioned groups, polymeric nanomaterials have already been used for wound dressings due to their multiple advantages. Among them, hydrogels are the most popular for biomedical applications [21]. Therefore, nanomaterials can generally be integrated into hydrogels for PTT, especially for treating bacterial infections. In this review, we summarize recent work, presenting an explanation of the synthesis principles and antibacterial mechanisms of nanomaterials and providing relevant results. After that, directives are also proposed according to current trends.

\section{Metal-Based Nanomaterials}

Metal-based nanomaterials have received great interest due to their unique optical properties, which are size- and shape-dependent [22-25]. Therefore, many kinds of metal nanostructures have been produced, such as nanorods [26-28], nanostars [29], nanobipyramids [30], nanowires [31-33], nanoworms (NWs) [34-36], nanoflowers [37,38], etc. Liao et al. focused on gold NWs (AuNWs) and synthesized them with an average diameter of $5 \pm 1.5 \mathrm{~nm}$ through a one-step synthesis method, as shown in Figure 1. After near-infrared (NIR) laser $(808 \mathrm{~nm}$ ) irradiation for $20 \mathrm{~min}$, AuNW solutions of 100 and $25 \mu \mathrm{g} / \mathrm{mL}$ induced increases in temperature of 30.9 and $14.2{ }^{\circ} \mathrm{C}$, respectively. After confirming the photothermal performance, the photothermal toxicities of AuNWs were evaluated through incubation with Escherichia coli (E. coli) and Staphylococcus aureus (S. aureus) using a plate counting method under a $1 \mathrm{~W} / \mathrm{cm}^{2}$ intensity of NIR laser irradiation. At the end of seven cycles of NIR laser irradiation, the photothermal stability of AuNWs had improved. With NIR irradiation, AuNWs revealed antibacterial activities of $>80 \%$ and $90 \%$ for E. coli and S. aureus, respectively. However, without NIR laser irradiation, AuNWs only showed antibacterial activities of $<20 \%$ for both E. coli and S. aureus [39]. 


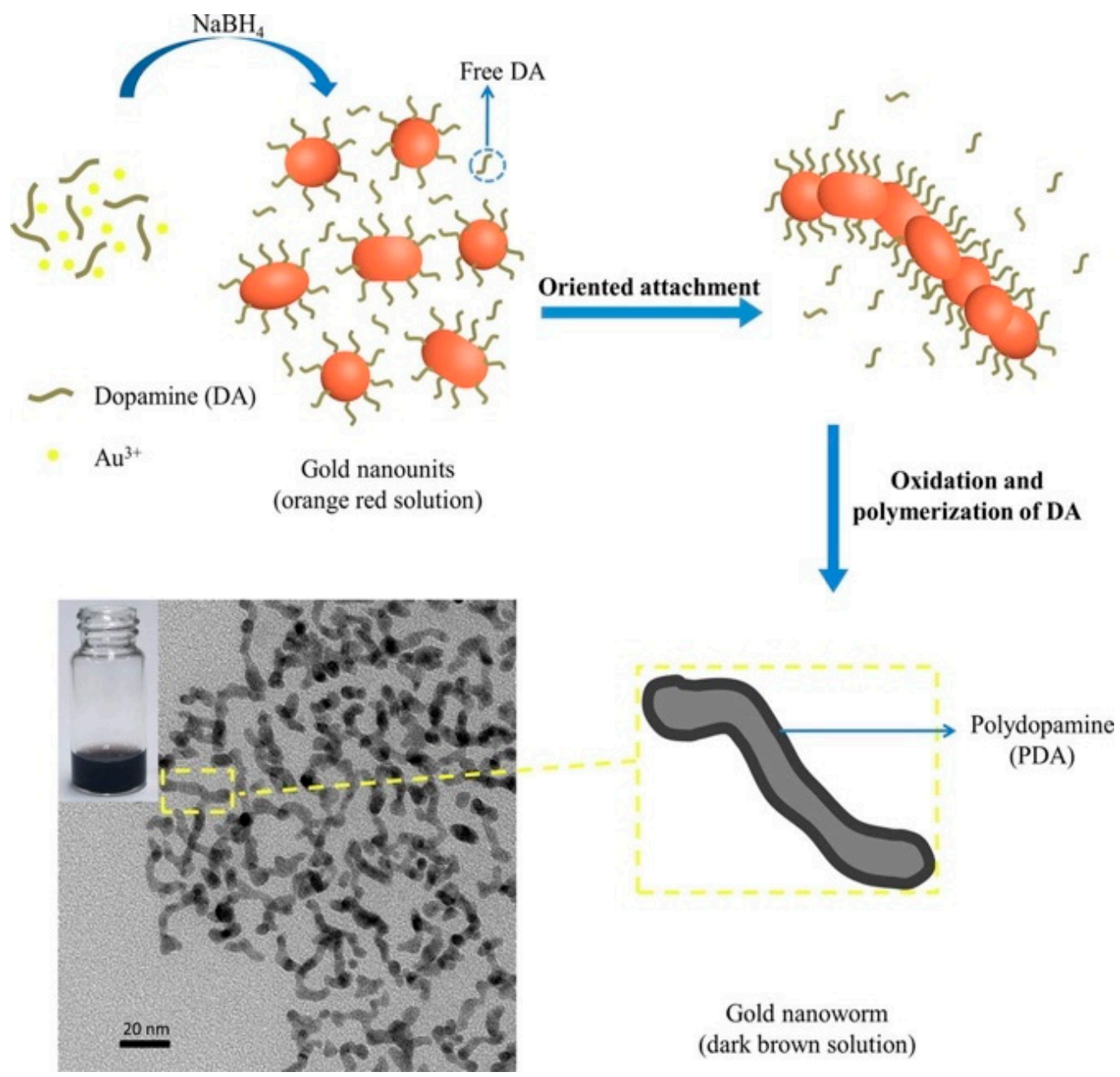

Figure 1. The proposed synthetic mechanism for the formation of gold nanoworms (AuNWs). Reproduced from [39], with permission from Elsevier, 2020.

Endotoxins secreted by certain bacteria can cause severe infections. Naturally produced biofilm also protects bacteria and increases the resistance to antimicrobial treatments. Therefore, designing materials capable of inhibiting endotoxins and biofilm formation or destroying them is a good way to fight superbugs. Li et al. fabricated protease-conjugated gold nanorods (PGs) for bacterial exotoxins and biofilm elimination under light illumination [40]. According to their work, PGs caused the degradation of nucleic acids and proteins of E. coli and S. aureus after NIR irradiation for $20 \mathrm{~min}$ (Figure 2). Hyperthermia generated by gold nanorods and protease activity induced the breakage of bacterial membranes and allowed the degradation of proteins and nucleic acids. Autoinducing peptide (AIP) plays an essential role in quorum sensing and was degraded by PGs. Therefore, inhibition of the AIP affects biofilm formation and broadens bacterial resistance. Their results also showed that PGs combined with NIR irradiation induced endotoxin destruction which was better than that of hyperthermia or protease alone. 

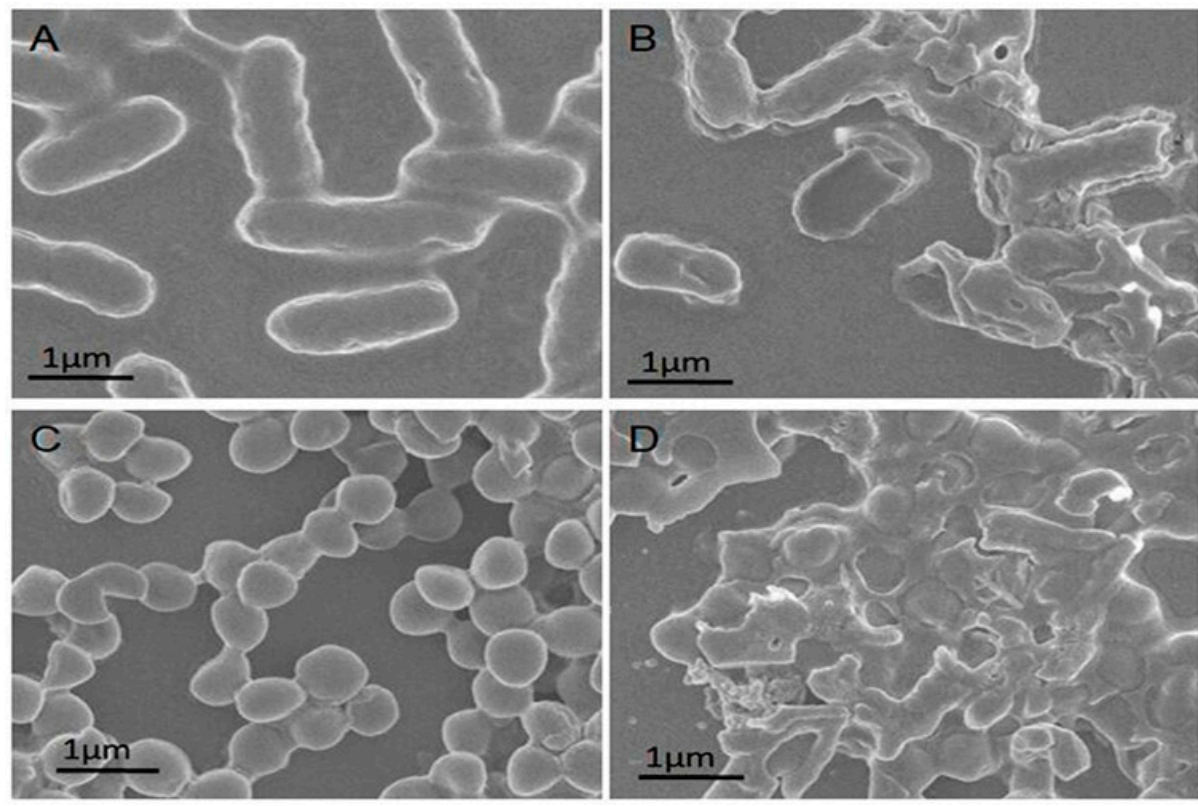

Figure 2. SEM images of (A) untreated Escherichia coli, (B) E. coli treated with protease-conjugated gold nanorods (PGs) $(50 \mu \mathrm{g} / \mathrm{mL})$, (C) untreated Staphylococcus aureus, and (D) S. aureus incubated with PGs $(50 \mu \mathrm{g} / \mathrm{mL})$ and near infrared (NIR) illumination for $20 \mathrm{~min}$. Reproduced from [40], with permission from Medical Press, 2019.

Molybdenum disulfide $\left(\mathrm{MoS}_{2}\right)$ nanosheets (NSs) are known to have an excellent photothermal performance and are capable of being functionalized by multiple biomolecules, such as poly(ethylene glycol) (PEG)-SH and immunoglobulin (Ig), and maintaining their properties. However, these conjugates are unstable in physiological solutions. Therefore, dopamine is used as an interface to assist with strong binding between $\mathrm{MoS}_{2}$ NSs and PEG-SH or IgG specific to the surface proteins of S. aureus. Synthesized nanocomposites are expected to exhibit a targeting ability, bacterial photothermal killing, and compatibility with surrounding cells of S. aureus. In the photothermal process, heat can affect surrounding healthy cells. Additionally, Yuwen et al. revealed the capability of biofilms to withstand heat or disturb heat dissipation [41]. To overcome these issues, metals with known photothermal effects were combined with organic compounds with specific properties, such as an affinity towards bacteria. Following this logic, one of the aims is to ensure that photothermally activated nanomaterials are situated close to the target bacterial cells. Therefore, Zhang and coworkers combined $\mathrm{MoS}_{2}$ silver nanocomposites with polydopamine (PDA). This $\mathrm{MoS}_{2}$-coated PDA was again coupled with PEG-SH and IgG of anti-protein A. The final nanocomposite was named MPPI NSs [42]. Concerning the capability of MPPI NSs to target $S$. aureus and Pseudomonas aeruginosa, biofilms were separately incubated with saline, $\mathrm{MoS}_{2} @ P D A-P E G(\mathrm{MPP})$, and MPP/IgG (MPPI) solutions for $6 \mathrm{~h}$. After incubation, images from scanning electron microscopy (SEM) allowed examination. In MPP NS solutions, SEM images showed an accumulation of crumpled MPP NSs on the biofilm surface due to a lack of specific binding. However, images from MPPI NS solutions displayed a crumpled sail of NSs covering bacterial cells in the biofilm. Energy-dispersive x-ray spectroscopy (EDS) also demonstrated a greater accumulation of MPPI NSs than MPP NSs on S. aureus biofilm through Mo and $S$ percentages. The targeting ability of MPPI NSs was confirmed through the results of a differential test with P. pseudomonas. To investigate bacterial photothermal killing by MPPI NSs, S. aureus biofilms were incubated with MPPI NSs and MPP NSs and irradiated with a 785-nm laser (at $0.58 \mathrm{~W} / \mathrm{cm}^{2}$ ) for $10 \mathrm{~min}$.

Temperatures reached 30 and $43{ }^{\circ} \mathrm{C}$ for MPP NS-biofilm and MPPI NS-biofilm blends, respectively. This showed that more MPPI NSs than MPP NSs had accumulated on the biofilm through specific binding to the antibody. Without laser irradiation, MPP NSs and MPPI NSs decreased the number of colony-forming units (CFU) on S. aureus biofilms by $57.08 \%$ and $77.07 \%$, respectively. However, 
after irradiation, this dropped to $89.14 \%$ for MPP NSs and $>99.99 \%$ for MPPI NSs at a concentration of $160 \mu \mathrm{g} / \mathrm{mL}$. This confirmed the effectiveness of targeted PTT. The in vivo photothermal efficacy was also evaluated with mice wound infection observations carried out for 8 days (Figure 3). The numbers of $S$. aureus colonies in the wound were found to be more than $99.99 \%$ for MPPI NSs and $48.43 \%$ for MPP NSs after irradiation.
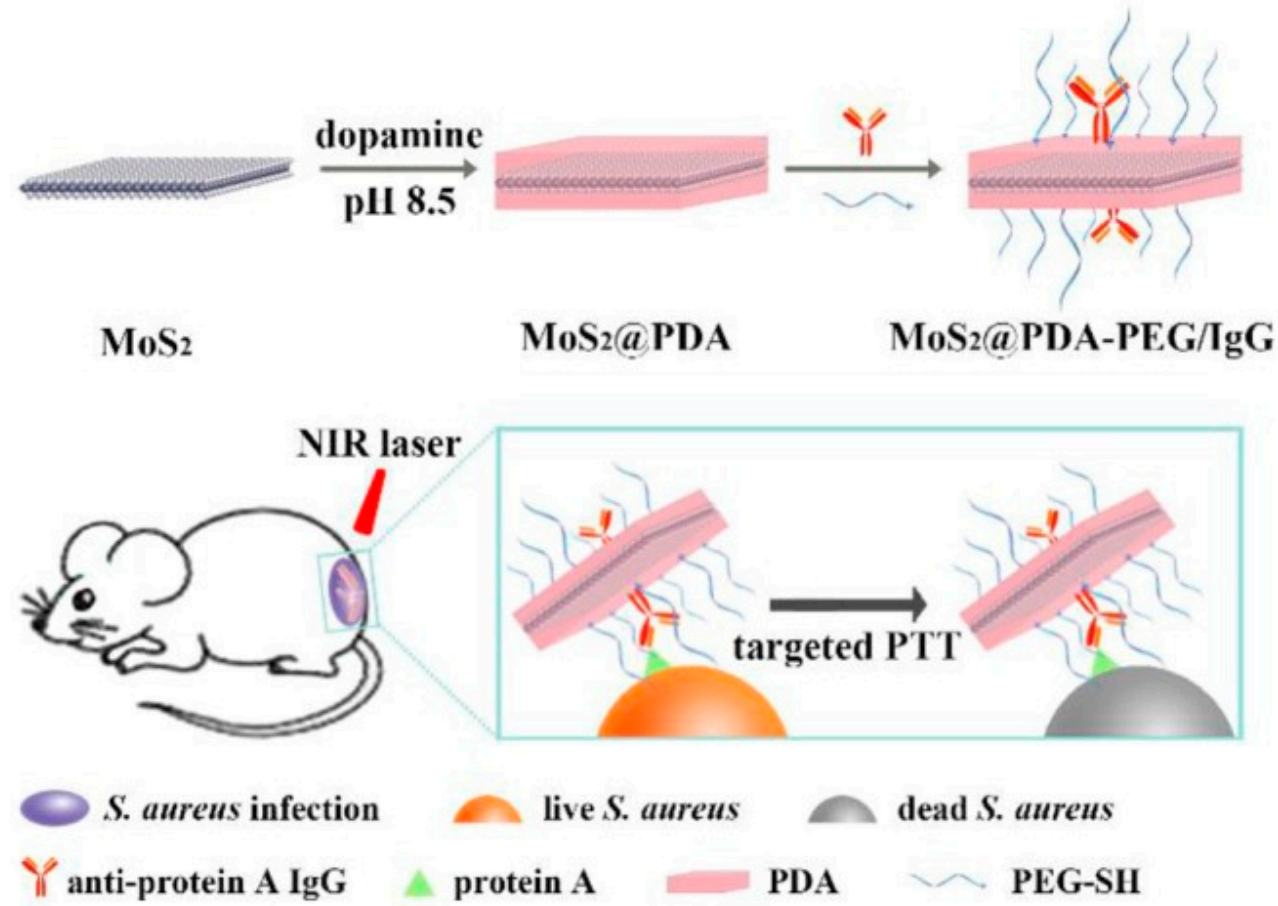

Figure 3. Preparation of $\mathrm{MoS}_{2} @ \mathrm{PDA}-\mathrm{PEG} / \mathrm{IgG}$ nanosheets (NSs) (MPPI NSs) and their application for the targeted photothermal therapy (PTT) of S. aureus focal infection. Reproduced from [42], with permission from Frontiers Media S.A., 2019.

Gold-silver nanostructures were found to possess plasmonic resonance in the NIR region $(\sim 800 \mathrm{~nm})$, making them effective photothermal candidates. Gold-silver bimetallic nanocomposites conjugated with aspartame were found to be effective antimicrobial agents under 808-nm laser irradiation. The macrophage-membrane@gold-silver nanocages were found to have enhanced microbial inhibition under laser irradiation with a specific bacterial targeting ability [43-45]. The recently reported novel nanomaterial silica-coated gold-silver nanocages (Au-Ag@ $\mathrm{SiO}_{2} \mathrm{NCs}$ ) showed reliable increases in microbial resistance under NIR laser irradiation compared to Au-Ag NCs alone [46]. The surface plasmon resonance of Au-Ag NCs was improved by coating them with silicon dioxide at 770 804 nm, which is nearly complimentary to the NIR region. When synthesized Au-Ag@SiO $\mathrm{NC}$ were subjected to an NIR laser at a concentration of $400 \mu \mathrm{g} / \mathrm{mL}$ in aqueous solution for 10 min, there was a swift increase in temperature from 20.7 to $60.1^{\circ} \mathrm{C}$. Increases in the concentration of $\mathrm{Au}-\mathrm{Ag} @ \mathrm{SiO}_{2} \mathrm{NCs}$ and the time of laser irradiation were directly proportional to an increase in temperature. This showed that the heat generated by this nanomaterial was rapid and able to eradicate Enterococcus faecium, Staphylococcus aureus, Klebsiella pneumoniae, Acinetobacter baumannii, Pseudomonas aeruginosa, and Enterobacter spp. (ESKAPE) pathogens (Figure 4) [47].

In vitro and in vivo studies have also shown an effective inhibition of bacteria under NIR laser irradiation. A silica coating of Au-Ag NCs not only enhanced the optical properties, but also assisted with the controlled release of silver ions for a prolonged period of time and showed enhanced antibacterial activity. The minimum bactericidal concentration (MBC) for $S$. aureus was found to be $128 \mu \mathrm{g} / \mathrm{mL}$ with an incubation period of $12 \mathrm{~h}$ and NIR laser irradiation (at an intensity of $1.5 \mathrm{~W} / \mathrm{cm}^{2}$ ) for $5 \mathrm{~min}$. The MBC for $E$. coli was $8 \mu \mathrm{g} / \mathrm{mL}$ under the same conditions as in previous 
studies. The photothermal killing of microbes was also evident for S. aureus biofilms, as confirmed by three-dimensional (3D) confocal laser microscopy (CLM). In vivo studies have reported the combined anti-infective effects of microbial growth inhibition and speedy wound healing in 7 days under NIR laser irradiation [48].

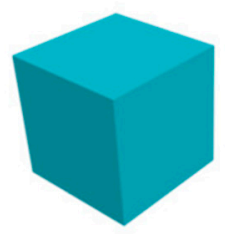

$\mathrm{Ag} \mathrm{NC}$

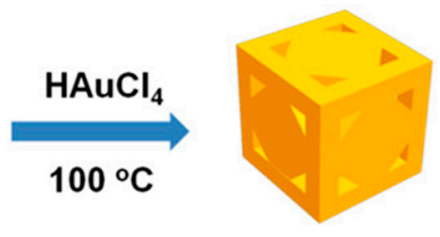

Au-Ag NC

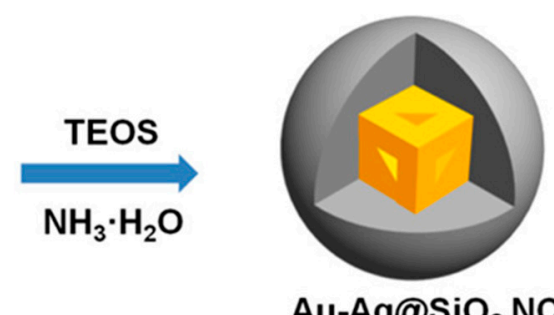

$\mathrm{Au}-\mathrm{Ag} @ \mathrm{SiO}_{2} \mathrm{NC}$
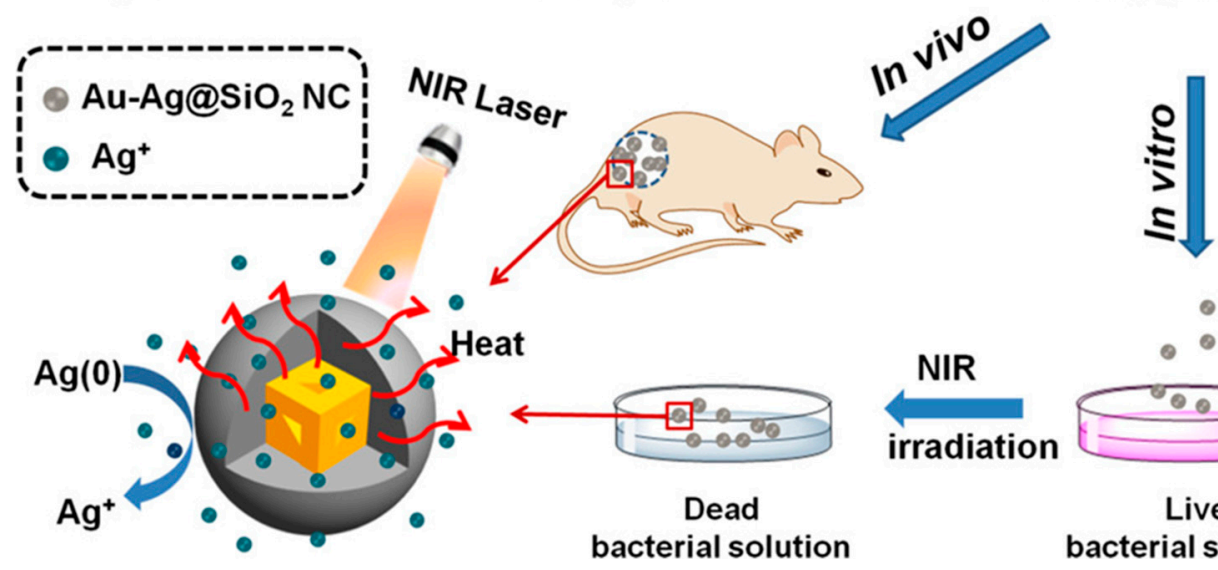

NIR

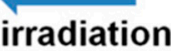

Live bacterial solution

Figure 4. Silica-coated gold-silver nanocages (Au-Ag NCs) showing antibacterial activity by a photothermal effect. Reproduced from [46], with permission from American Chemical Society, 2019.

Ag-doped $\mathrm{TiO}_{2}$ exhibited enhanced antibacterial activity against gram-positive bacteria (GPB) and gram-negative bacteria (GNB) compared to crude titanium dioxide under visible light irradiation [49]. The antibacterial activity displayed by Zn-doped titanium dioxide thin films was also notable compared to $\mathrm{TiO}_{2}$ or $\mathrm{ZnO}$ alone under the influence of visible and NIR light irradiation [50]. $\mathrm{Au}-\mathrm{TiO}_{2}$ on a graphene monolayer (GTA) exhibited significant bactericidal effects compared to its counterparts of $\mathrm{TiO}_{2}$, graphene, and a $\mathrm{TiO}_{2}$-graphene layer under the influence of light irradiation [51]. One recent study showed that gold nanorods (AuNRs) coated on the surface of titanium displayed microbial resistance against the gram-negative bacteria, E. coli and Pseudomonas aeruginosa (P. aeruginosa), with an enhanced photothermal effect by NIR irradiation and a high cell viability. Titanium in the present scenario is important in implants for clinical applications, and AuNRs on the titanium surface were found to be very effective against GPB and GNB [52]. The antimicrobial efficiencies of Ti-AuNRs towards E. coli, P. aeruginosa, S. aureus, and Staphylococcus epidermidis (S. epidermidis) under NIR laser irradiation were $61.82 \%, 66.74 \%, 26.31 \%$, and $31.84 \%$, respectively. The results indicated that the gram-negative bacilli, E. coli and P. aeruginosa, demonstrated a higher efficiency compared to two other gram-positive Coccus counterparts (Figure 5). The surface area, size, and shape of the bacteria are also important factors to be considered, and in this case, the bacillus, rod-shaped bacterium complimented the shape of AuNRs, and AuNRs were more effective against rod-shaped bacilli. AuNRs are less effective against coccus-shaped bacteria, as there is more gluing with rod-shaped bacilli compared to cocci. It was proven that the light absorbed by AuNPs can be transformed into heat, leading to the degradation of bacterial cell walls. The antimicrobial activity displayed by photothermal microbial treatment is more extensively used and a more notable technique, especially AuNRs, which are more capable candidates with NIR laser irradiation [52-58]. 


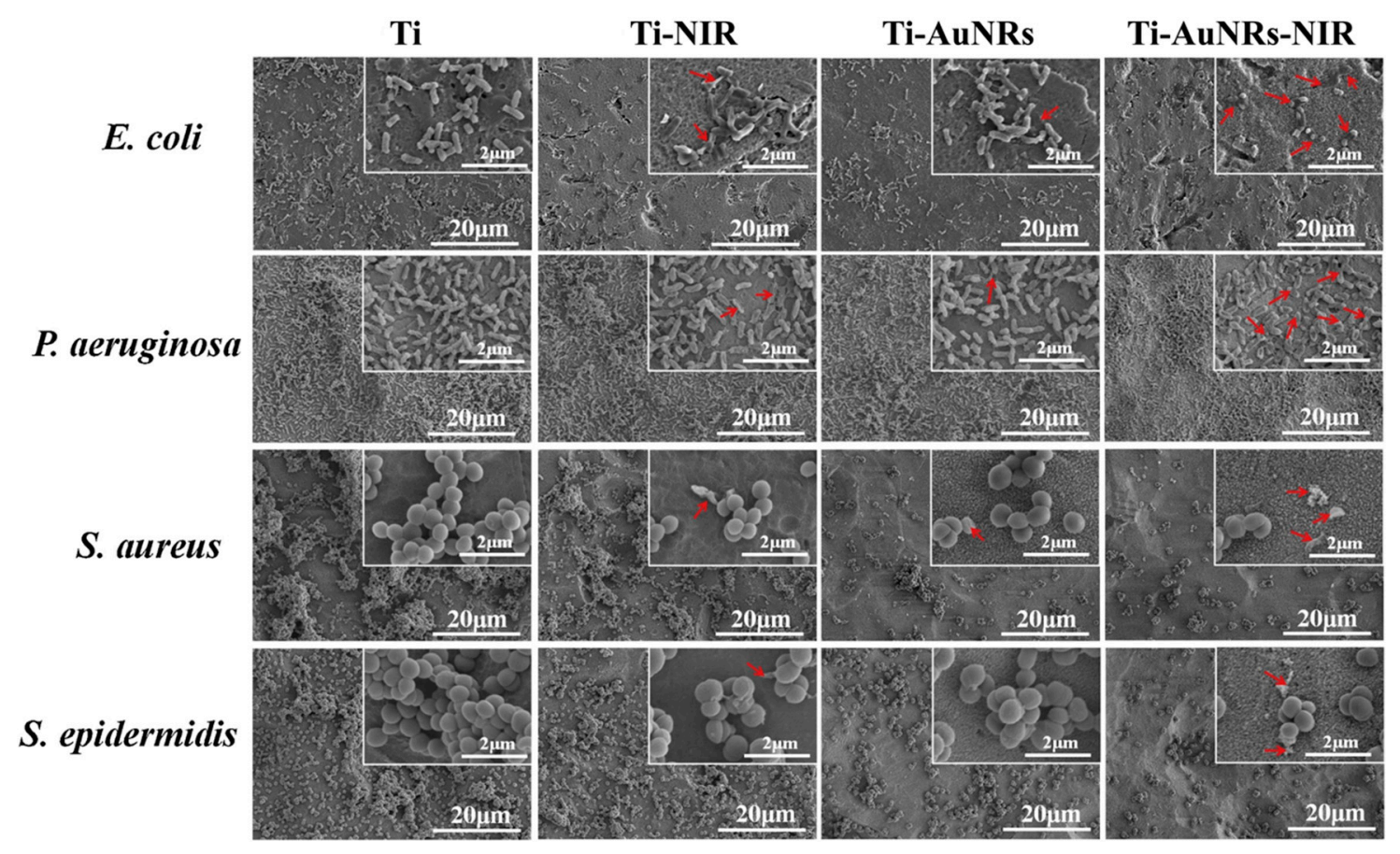

Figure 5. SEM images of E. coli, Pseudomonas aeruginosa, S. aureus, and S. epidermidis on titanium (Ti) and Ti-gold nanorod (Ti-AuNRs) surfaces before and after NIR irradiation (20 min); the bacteria concentration was $10^{7}$ colony-forming units/mL. Red arrows show the damaged microbial cell structure.

Reproduced from [52], with permission from Elsevier, 2019.

Gold nanoclusters coated with DNase (DNase-AuNCs) fabricated by Xie et al. showed the capability to kill both GPB and GNB. The DNase-AuNCs were toxic to planktonic bacteria and biofilms. Bacterial extracellular matrix was broken up by DNase, exposing bacterial strains to reactive oxygen species (ROS) and the heat from gold nanoclusters after NIR 808-nm laser irradiation $\left(2 \mathrm{~W} / \mathrm{cm}^{2}\right)$ for $10 \mathrm{~min}$ [59]. With $800 \mu \mathrm{g} / \mathrm{mL}$ of gold nanoclusters, the temperature of DNase-AuNCs reached $63^{\circ} \mathrm{C}$ under 808-nm laser illumination for $10 \mathrm{~min}$. Using DNase-AuNCs, bacterial inhibition ratios were $35 \%$ and $60 \%$ due to the ROS and heat generated under light irradiation, respectively. Moreover, the combined bacterial inhibition ratio was $90 \%$, which confirmed that DNase-AuNCs furnish good photothermal and photodynamic synergistic effects upon NIR illumination (Figure 6).

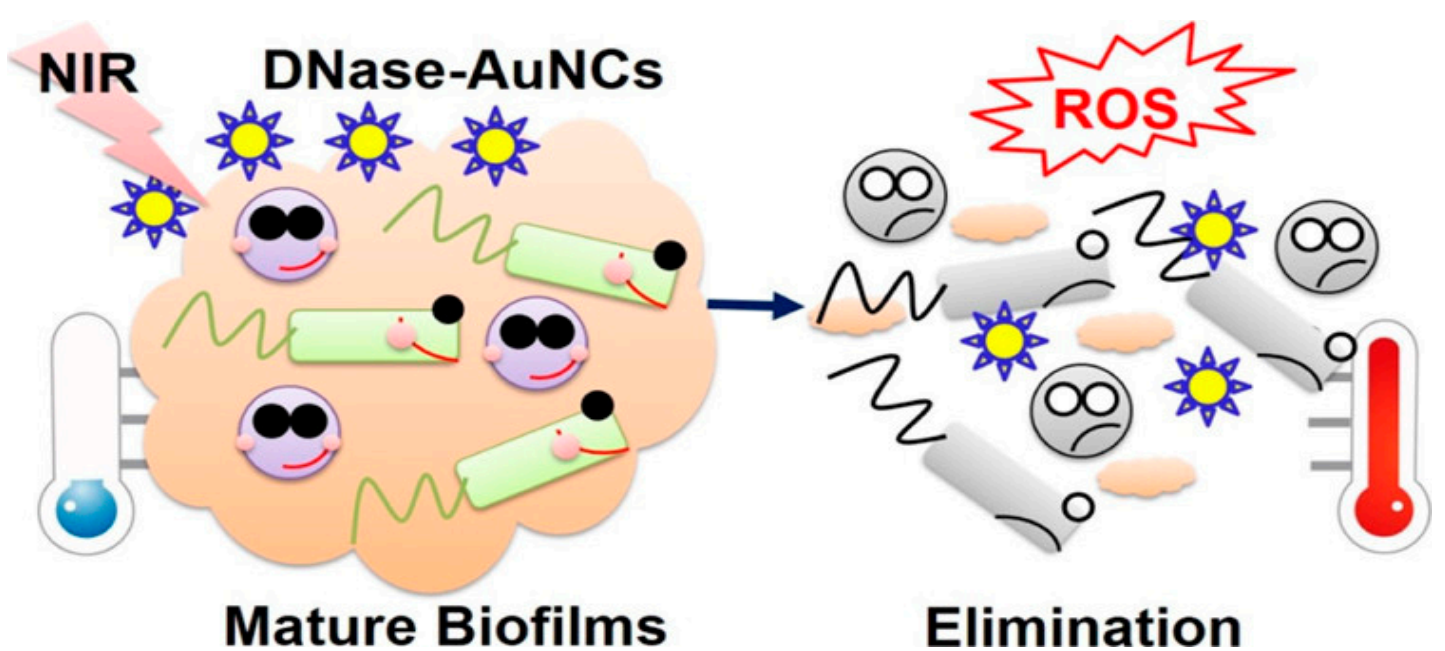

Figure 6. Mechanism of biofilm elimination by gold nanoclusters coated with DNase (DNase-AuNCs) under NIR irradiation. Reproduced from [59], with permission from American Chemical Society, 2020. 


\section{Carbon-Based Nanomaterials}

Among the carbon-based nanomaterials previously listed, graphene oxide (GO), one of the carbon derivatives, possesses photothermal properties. Recently, phosphorous has aroused great interest due to its wide availability and eco-friendly properties. Amorphous red phosphorous (RP) has also been explored for bacterial inactivation. According to the advantages of RP, which is capable of absorbing NIR light, Zhang et al. fabricated a phosphorous film deposited on a Ti plate (Ti-RP). Moreover, the photoelectrochemical performances were improved by a GO layer coated onto the film. The final nanocomposite was called RP/GO film [60]. E. coli and S. aureus at $10^{7} \mathrm{CFU} / \mathrm{mL}$ mixed with RG/GO were about $99.9 \%$ inactivated under irradiation with simulated sunlight (SSL) and NIR light for $20 \mathrm{~min}$ at 0.2 or $0.6 \mathrm{~W} / \mathrm{cm}^{2}$. Irradiation under light-emitting diodes (LEDs) and visible light also induced good bacterial toxicity (Figure 7).

A

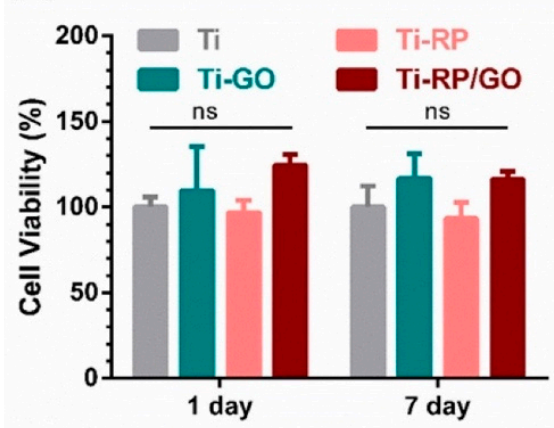

C
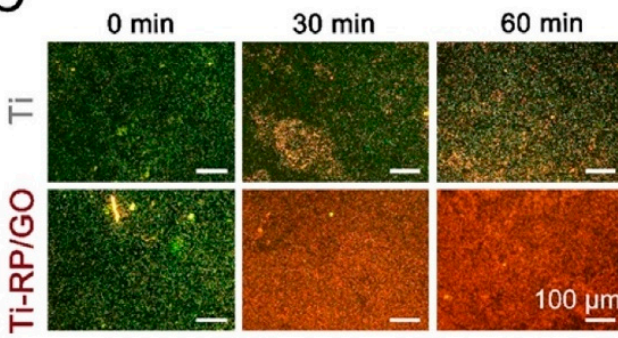

E

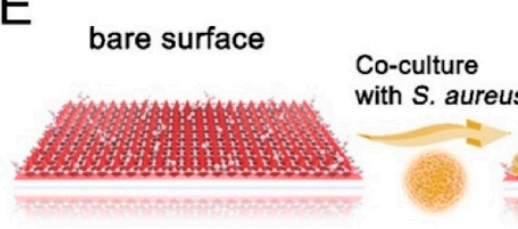

B

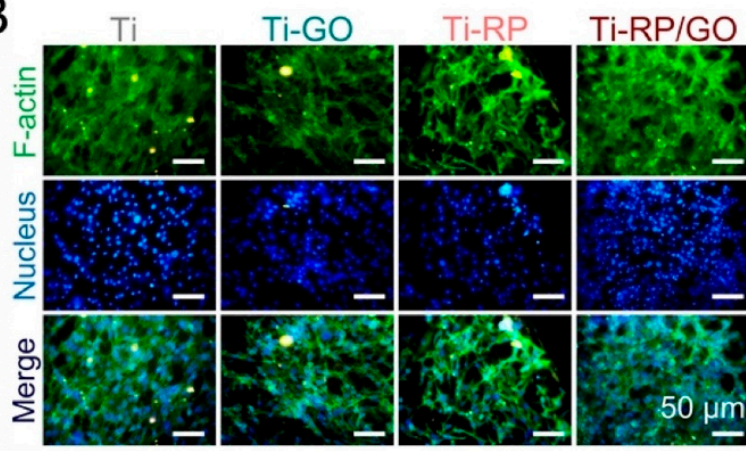

D

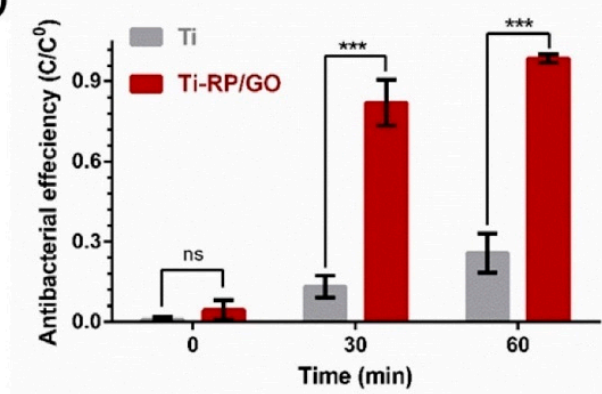

Figure 7. Cellular response to (A) the cytotoxicity of NH3T3 cells after co-culturing for 1 and 7 days and (B) fluorescence staining on the surfaces of samples after co-culturing with NH3T3 cells for $24 \mathrm{~h}$. (C) The fluorescent assay of Staphylococcus aureus biofilm after irradiation with LED light (at $\left.0.1 \mathrm{~W} / \mathrm{cm}^{2}\right)$. Green represents living bacteria, while red represents dead bacteria. (D) Quantitative analysis of the fluorescent assay by Image J software. (E) Schematic diagram of biofilm dispersion. Reproduced from [60], with permission from Elsevier, 2020.

The photothermal conversion efficiency of gallic acid-conjugated silver (GA-Ag) NPs was found to be $48.70 \%$, which is higher than that of other nanocomposites, such as PEG-conjugated $\mathrm{MoS}_{2}$ nanoflowers, CuS nanodots, bismuth selenide nanospherical sponges, platinum NPs, and Prussian blue nanocages [61,62]. As previously mentioned, photothermal conversion was higher for GA-Ag NPs than other nanocomposites, making it an effective candidate against antibiotic-resistant microbes. This composite exhibited the effective killing of harmful disease-causing microbes with a swift increase in temperature and the release of silver ions. GA-Ag NPs embedded into carrageenan hydrogels not 
only exhibited an improved antibacterial effect with 808-nm NIR laser irradiation, but also displayed better wound healing with a photothermal effect in an in vivo rat model. The hydrogels also enhanced the absorbance of NIR radiation by silver ions and assisted with the controlled and speedy release of silver ions. The heat released by GA-Ag NP hydrogels was found to be sufficient to eradicate pathogenic bacteria known to cause vicious infections, and the heat released by these NPs promoted a rapid wound-healing effect. GA-Ag NP hydrogels were found to be effective agents against harmful disease-causing microbes, as well as in speedy wound recovery (Figure 8). GA-Ag NP hydrogels were recently reported to be an effective antimicrobial agent under NIR laser irradiation compared to GA-Ag NP hydrogels alone. NIR laser irradiation at $2 \mathrm{~W} / \mathrm{cm}^{2}$ for $10 \mathrm{~min}$ eliminated up to $98.7 \%$ and $94.8 \%$ of the microbes E. coli and S. aureus, respectively. An in vitro bacterial culture also indicated similar results.

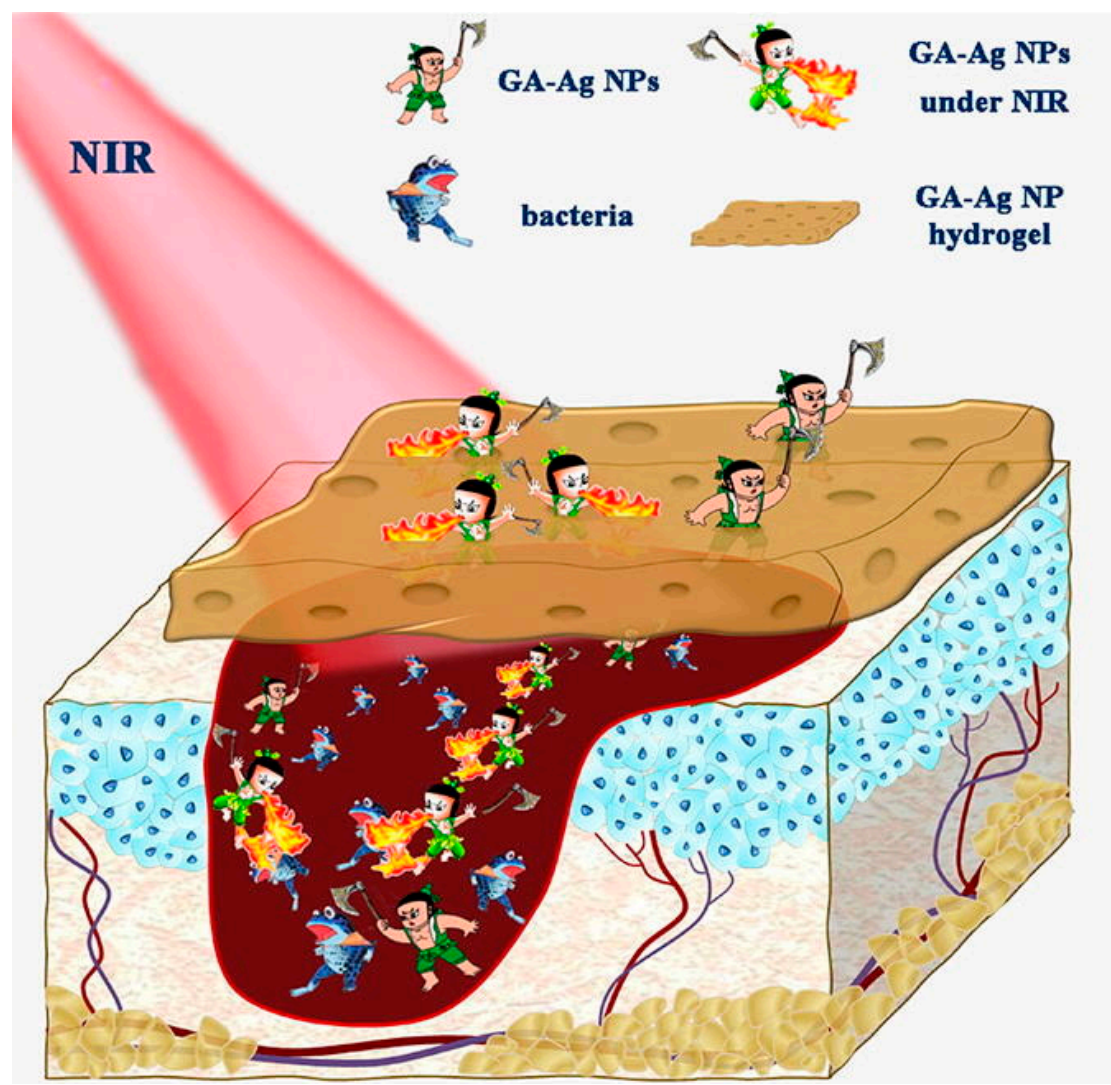

Figure 8. Schematic representation of the photothermal mechanism of antibacterial activity by gallic acid-conjugated silver nanoparticles (GA-Ag NPs). Reproduced from [61], with permission from Elsevier, 2020.

There are some examples which are correlated with the present study of GA-Ag NP hydrogels; in the presence of NIR laser radiation, copper sulfide NPs combined with bovine serum albumin (BSA-CuS) nanocomposites showed an enhanced efficiency of photothermal conversion and photothermal effects leading to the elimination of antibiotic-resistant GPB and GNB [63,64]. $N, N^{\prime}$-Di-sec-butyl- $N, N^{\prime}$-dinitroso-1,4-phenylenediamine (BNN6) conjugated with $\mathrm{MoS}_{2}$ nanovehicles also exhibited an enhanced killing of bacteria under the influence of NIR laser irradiation [65]. Degradation of the microbial cell envelope was elevated with an increase in temperature caused by GA-Ag NPs under NIR laser irradiation. Microbes were labeled with fluorescent markers, i.e., green fluorescence for live bacterial cells and red fluorescence for dead bacterial cells, and viewed with confocal laser scanning microscopy (CLSM). CLSM images revealed GA-Ag NP hydrogels under NIR laser irradiation compared to GA-Ag NPs alone. In vivo studies demonstrated improved wound 
healing at 7 days with GA-Ag NPs under NIR laser irradiation. SEM images also indicated similar results, as effective microbial cell wall degradation was observed with GA-Ag NP hydrogels combined with NIR laser irradiation. The heat generated by the photothermal effect led to protein coagulation and degradation of the cell envelope. In that study, the broad-spectrum infection carriers, E. coli and S. aureus, were successfully eliminated to the maximum limit [66-69]. Staphylococcus aureus-infected wounds showed better microbial inhibition and wound-healing capability by the seventh day with combined GA-Ag NP hydrogel and NIR laser irradiation treatment. The temperature due to laser irradiation reached $50.6^{\circ} \mathrm{C}$ near the wound region from $36.4{ }^{\circ} \mathrm{C}$ for GA-Ag NPs, indicating effective microbial inhibition compared to their counterparts. Hematoxylin and eosin (H\&E) staining showed an acute inflammatory response due to laser irradiation, and there was accelerated wound healing [61].

Quaternized chitosan (QCS)-conjugated ferric oxide NPs on the GO surface under NIR laser light displayed a good bacterial inhibitory capability. The photothermal efficacy of chitosan combined with magnetic GO (GO-IO-CS) was found to be effective for microbial inhibition under NIR laser irradiation. Gold nanoshells coated with reduced GO showed a better photothermal conversion efficiency than gold nanoshells or GO alone. Magnetically reduced GO-conjugated glutaraldehyde (MRGOGA) was found to be effective in eradicating ESKAPE pathogens under NIR laser irradiation (10 min), with up to a 99\% efficiency. A recent study revealed that Ag-NPs embedded in reduced GO (RGO/Ag) nanocomposites were effective and enhanced inhibition against multidrug-resistant (MDR) bacteria under NIR laser light (at an intensity of $0.30 \mathrm{~W} / \mathrm{cm}^{2}$ ) [70-73]. RGO/Ag nanocomposites were found to be effective antibacterial agents under NIR laser light against ESKAPE pathogens which exhibited antibiotic resistance. In recent times, MDR bacteria possessed by pathogens has become a greater issue, with limited or no solutions. RGO/Ag nanocomposites were found to be effective in tackling this crisis situation. The combination of Ag NPs and RGO increased absorption in the NIR region, which in turn led to an increased photothermal conversion efficiency. The photothermal efficiency of RGO/Ag nanocomposites was found to be better than GO, RGO, or Ag NPs alone. This led to the enhanced photothermal killing of MDR bacteria under NIR light at a power density of $0.30 \mathrm{~W} / \mathrm{cm}^{2}$ for $10 \mathrm{~min}$ (Figure 9). There was alleviation in the temperature showing potential microbial inhibition, with a minimal concentration of RGO/Ag nanocomposites and a low power density of NIR laser light. In that study, two bacteria, E. coli and K. pneumoniae, displayed respective minimum inhibitory concentrations (MICs) of 15 and $30 \mu \mathrm{g} / \mathrm{mL}$ under 808-nm laser light, and the antibacterial efficiencies were found to be $98.2 \%$ and $97.6 \%$. RGO/Ag nanocomposites were effective photothermal agents, and the RGO coating prolonged the release of silver ions. NIR laser radiation for 10 min showed half-MICs for E. coli and K. pneumonia of 9 and $17 \mu \mathrm{g} / \mathrm{mL}$, respectively. RGO/Ag is believed to be the most effective photothermal antibacterial agent at the present time when compared to GO, RGO, or Ag NPs alone. Two fluorescent nucleic acids, 4',6-diamidino-2-phenylindole (DAPI) and propidium iodide (PI), were used to stain E. coli cells. Fluorescent images also showed enhanced antibacterial activity under NIR laser irradiation for $10 \mathrm{~min}$. There was irreparable damage caused to bacterial cell envelopes under NIR laser irradiation, as confirmed by fluorescence images [74-77].

A nanocomposite from graphene nanoribbons (GNRs) and polycationic porphyrin (Pp4N) was fabricated by $\mathrm{Yu}$ and coworkers using a simple self-assembly method [78]. Due to the hydrophobic character of graphene, GNRs were conjugated with poly(ethylene oxide) (PEO) to obtain the hydrophilic form (GNR-PEO2000). GNR-PEO2000 carries a negative charge, Pp4N carries a positive charge, and the composite Pp4N/GNR was obtained by electrostatic attraction using sonication. Upon 808-nm laser irradiation (at $1 \mathrm{~W} / \mathrm{cm}^{2}$ ), GNRs induced a time-dependent temperature increase, reaching $53{ }^{\circ} \mathrm{C}$ in 10 min, which was similar to that caused by Pp4N/GNR-PEO2000 nanocomposites. More interestingly, GNRs turned out to be a capture agent for GNB and GPB. Under 808-nm laser irradiation, the composite reduced the bacterial viability to $30.8 \%$. When NIR laser irradiation was followed by visible wavelength irradiation, the bacterial viability decreased to $14.3 \%$ (Figure 10). 


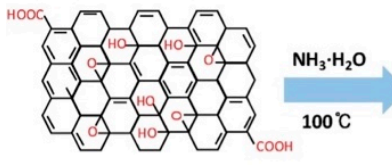

GO

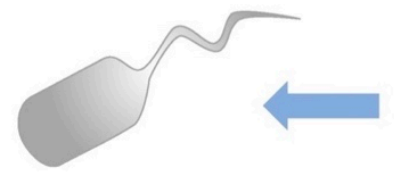

Dead bacteria

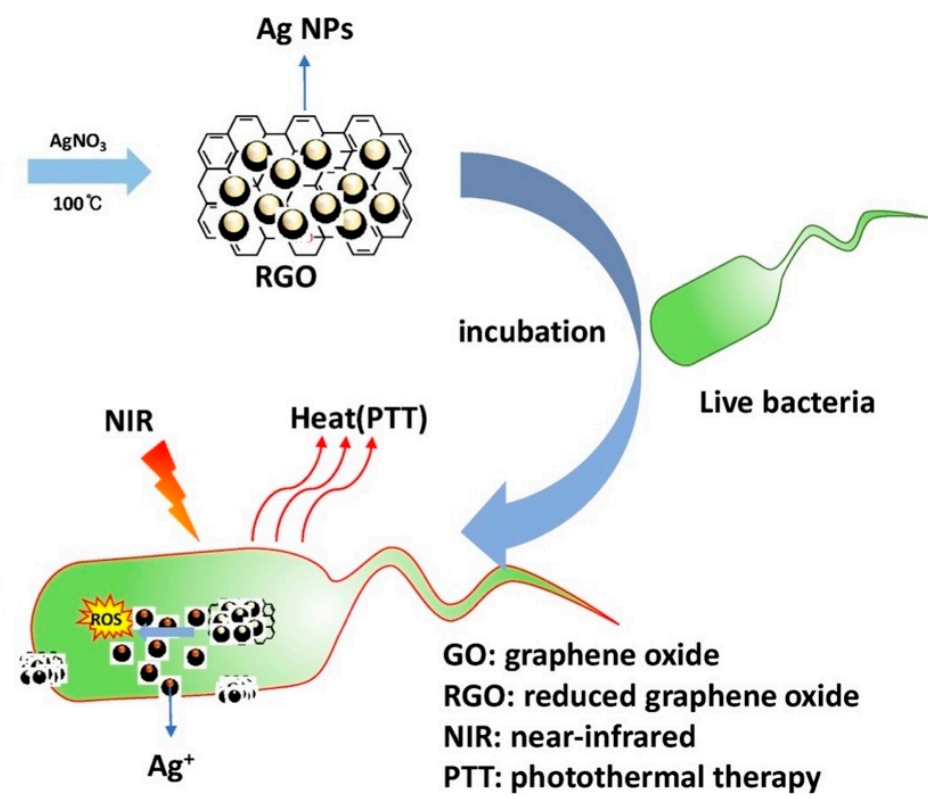

Figure 9. Schematic representation of the photothermal killing of microbes by silver nanoparticles (Ag NPs) embedded in reduced graphene oxide (RGO/Ag). Reproduced from [73], with permission from Elsevier, 2020.
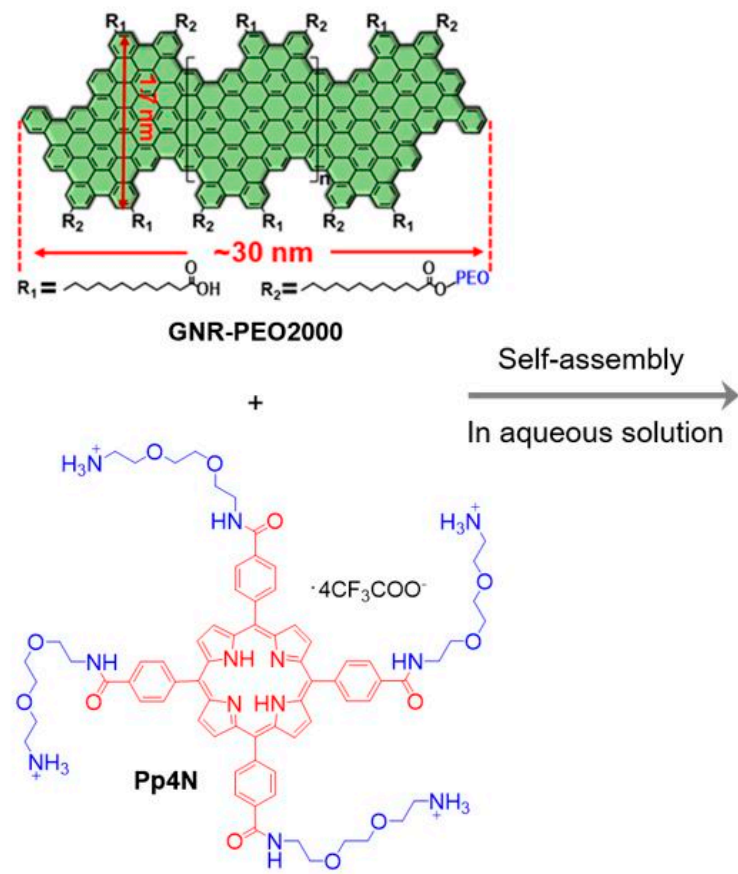

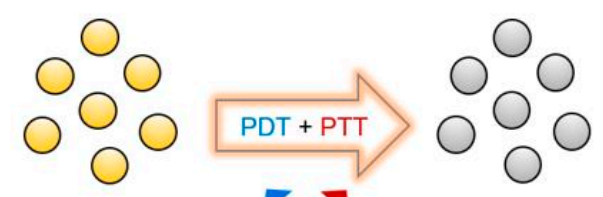

Superbugs - Live Superbugs - Dead $808 \mathrm{~nm}$

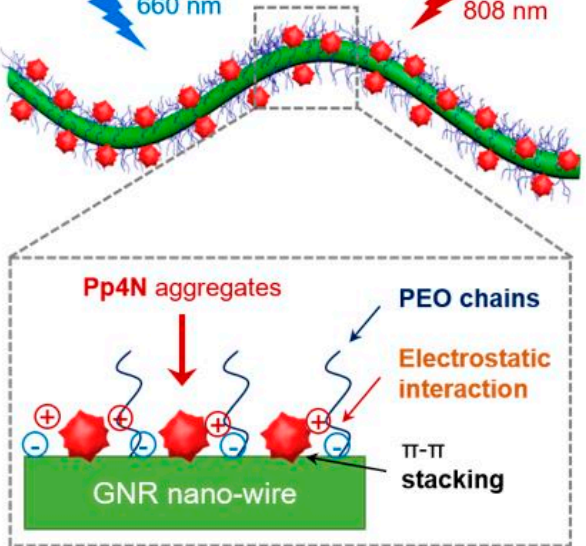

Figure 10. Structures of cationic porphyrin $(\mathrm{Pp} 4 \mathrm{~N})$ and water-dispersible graphene nanoribbons (GNRs) with a poly(ethylene oxide) (PEO) grafting percentage of 42\% (GNR-PEO2000) used for self-assembly and double-light activated photodynamic and photothermal therapy of drug-resistant bacteria (superbugs). Reproduced from [78], with permission from John Wiley and Sons, 2020.

\section{Polymer-Based Nanomaterials}

Hydrogels present multiple advantages for wound dressings, such as oxygenation, water permeability, the preservation of a moist microenvironment, etc. [79-83]. Inorganic nanomaterials such as metals [84], transition metals [85], and carbon-based nanomaterials [86] with a photothermal effect can be incorporated into hydrogels to improve the photothermal capacities. Although inorganic 
nanomaterials are better photothermal agents, organic nanomaterials also exhibit the same properties. Therefore, organic compound-doped hydrogels were used as photothermal antimicrobials $[87,88]$ and have the advantage of being cost-effective.

Based on the photothermal effect of tannic acid-Fe (Ta-Fe) [89], and favorable properties of agarose (AG) for biological applications, such as being thermoresponsive and biocompatible [90,91], Deng et al. synthesized Ta-Fe composites (ATFs). ATFs revealed wide absorption in NIR wavelengths of 500 900 nm. Therefore, upon 808-nm laser irradiation, the temperature of ATF increased and was dependent on the laser intensity and irradiation time [92]. After NIR irradiation for $10 \mathrm{~min}$, followed by a bacteriostatic ring test, ATF hydrogels induced an inhibition zone diameter of $15 \mathrm{~mm}$ with $S$. aureus. Wounds infected with S. aureus, treated with ATF hydrogels, and irradiated exhibited the occurrence of scabs and less edema. The number of colonies after quantification revealed a significant decrease compared to the control group (Figure 11).
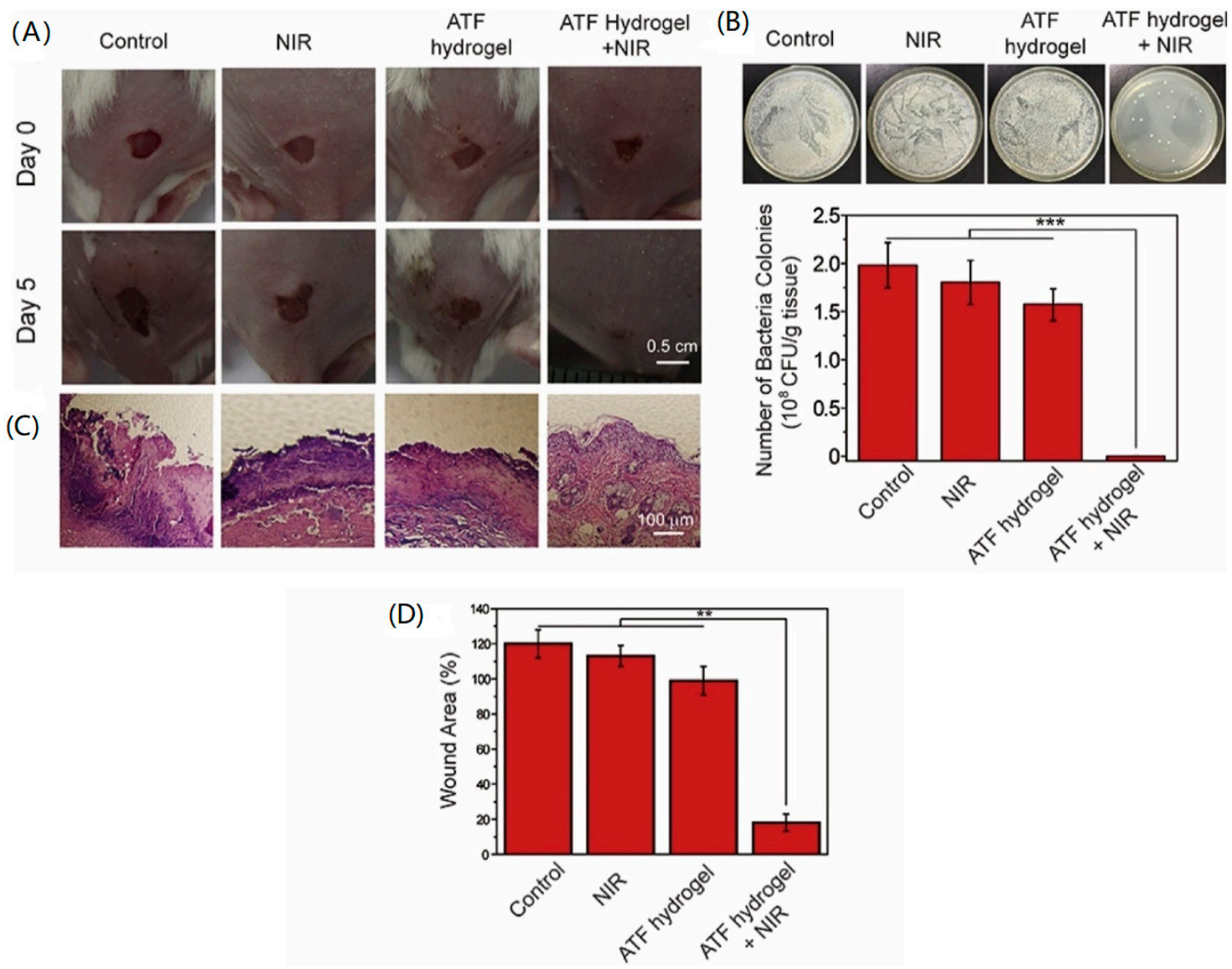

Figure 11. (A) Digital images of S. aureus-infected wounds of mice before treatment and after different treatments on day 5. (B) Digital images and histograms of S. aureus colonies derived from homogenized dispersions of the wounds of mice with different treatments, ${ }^{* * *} p<0.001$. (C) Digital images of hematoxylin and eosin (H\&E)-stained wound sections in mice at day 5 with different treatments. (D) The corresponding statistical diagram of wound area healing rates of mice in (A). Data are presented as the mean \pm SD from six parallel experiments per group $(n=6) .{ }^{* *} p<0.01$. Reproduced from [92], with permission from Elsevier, 2020.

Huang et al. reported that ferric oxide combined with gold nanoeggs functionalized with vancomycin displayed extraordinary antibacterial activity under NIR light irradiation, and there was a significant temperature increase of $32{ }^{\circ} \mathrm{C}$ in $3 \mathrm{~min}$. Polyaniline combined with glycol chitosan NPs was found to be effective against disease-causing microbes under NIR laser light irradiation. Wei Qian and co-workers showed that glycol chitosan combined with carboxyl graphene was better against 
disease-causing methicillin-resistant $S$. aureus (MRSA) when treated with an NIR laser, and with a controlled $\mathrm{pH}$, speedy wound recovery was observed [93-95]. Polymeric nanomaterials were found to be effective in recent studies; polyurethane-conjugated gold nanorods coated with PEG (PU-Au-PEG) nanocomposites were effective anti-infective materials under 808-nm NIR light [96]. PU-Au-PEG nanocomposites were found to be effective against both GNB and GPB under 808-nm NIR light. Gold nanorods possessed a better photothermal efficacy. The photothermal efficiency of gold nanorods was found to have increased when conjugated with PEG and polyurethane under NIR light irradiation. In that work, in vitro and in vivo studies showed the efficient killing of pathogens under NIR light by PU-Au-PEG nanocoatings. Polymer nanocoatings on gold nanorods also demonstrated a better eradication of bacteria when tested with biofilms under NIR light. CLSM images showed the effective killing of disease-causing microbes under NIR light for $10 \mathrm{~min}$. With PU-Au-PEG nanocomposites under NIR light irradiation for $10 \mathrm{~min}$, the temperature increased from 20 to $55^{\circ} \mathrm{C}$, revealing a better photothermal efficiency than other components used alone. In that study, two pathogens, $P$. aeruginosa and S. aureus, which are ESKAPE pathogens, were successfully eliminated with 10 min of NIR irradiation. The study showed high bacterial elimination efficiencies due to the photothermal effect (Figure 12). The results were supported by the better antibacterial activities exhibited by these nanocomposites, and the polymers used in the work did not allow microbial adhesion. The study revealed improved antimicrobial activity supported by in vitro and in vivo studies. The antimicrobial activity was observed to only be effective with irradiation using 808-nm light. The PU-Au-PEG nanomaterial used was active under NIR light, biocompatible, and stable, and exhibited an enhanced killing of bacteria [97-104].

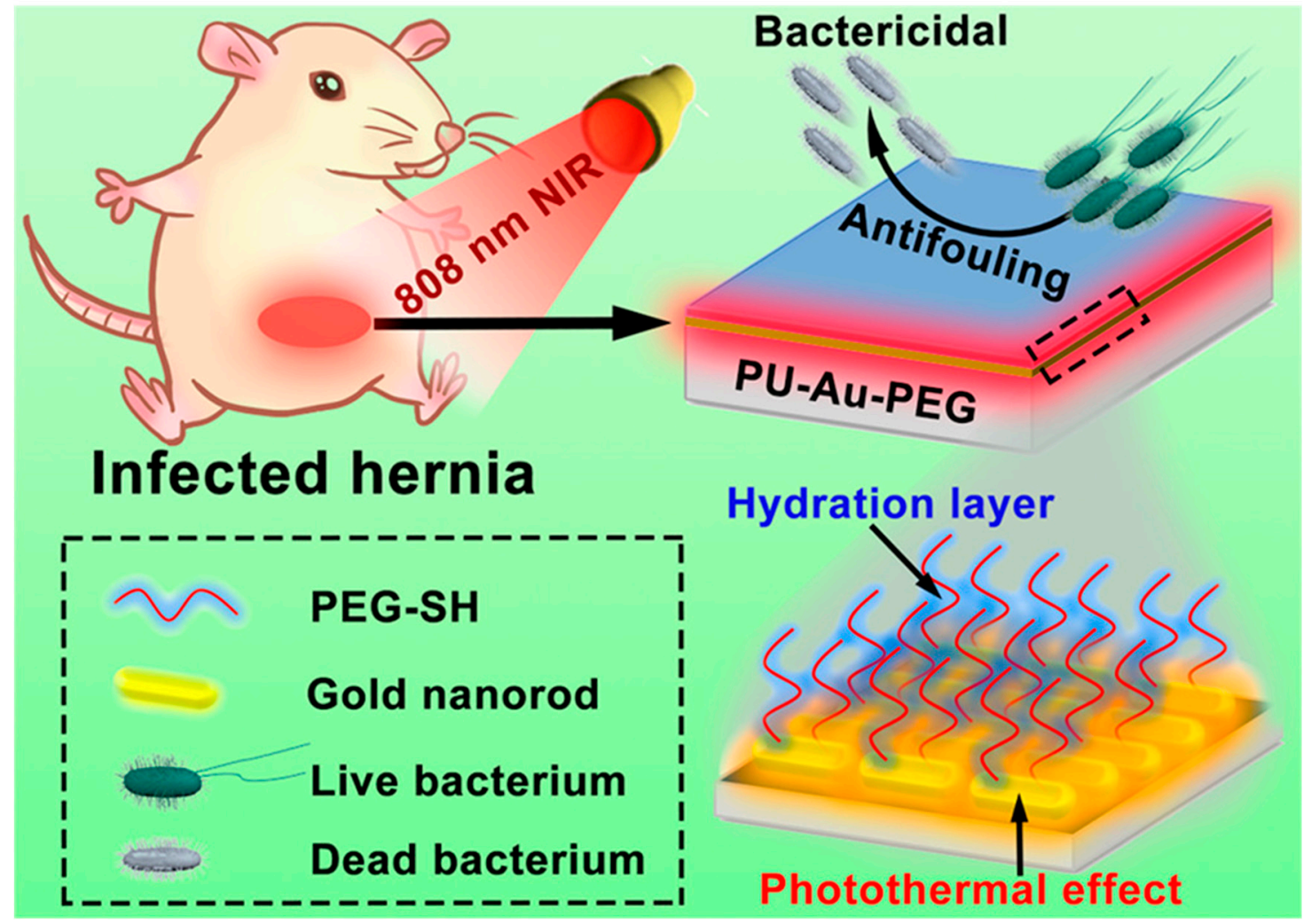

Figure 12. Antibacterial activity of polymeric gold nanorods due to a photothermal effect. Reproduced from [96], with permission from American Chemical Society, 2020.

Dithiols are known to have a greater compatibility with Au NPs. When dithiols are conjugated with $\mathrm{Au}$ NPs, the biocompatibility and stability of the latter are increased. Thiol-chitosan gold nanoshells (TC-AuNSs) were reported to display an enhanced bactericidal effect due to the photothermal effect. 
The thin layer of gold coating over the silica core and conjugation with thiol-chitosan for enhanced stability and application of these gold nanoshells to the bacteria and NIR irradiation impacted the photothermal killing of bacteria (Figure 13) [105,106]. The photothermal efficiency was comparatively high for TC-AuNSs, and the photothermal efficiency was positively affected by an increase in the concentration of TC-AuNSs and the intensity of NIR radiation. The increased concentration of TC-AuNSs and laser radiation intensity were directly proportional to a swift increase in temperature (enhanced photothermal effect) and upgraded antibacterial activity. The combined ability of TC-AuNSs and NIR laser irradiation caused irreparable harm to the cell walls of microbes (Figure 13) [106-110]. Human pathogenic bacteria such as S. aureus, P. aeruginosa, and E. coli are disease-causing agents because of their increased antibiotic resistance. TC-AuNSs were found to be very effective in eliminating these harmful microbes. Using PTT, gold nanostars (GNSs) displayed an excellent antibacterial efficiency of up to $99.99 \%$ [111]. Antibiotic-loaded gold nano-constructs demonstrated an enhanced antimicrobial resistance against MRSA with PTT, throwing light on a new approach to deal with antibiotic-resistant bacteria [112].

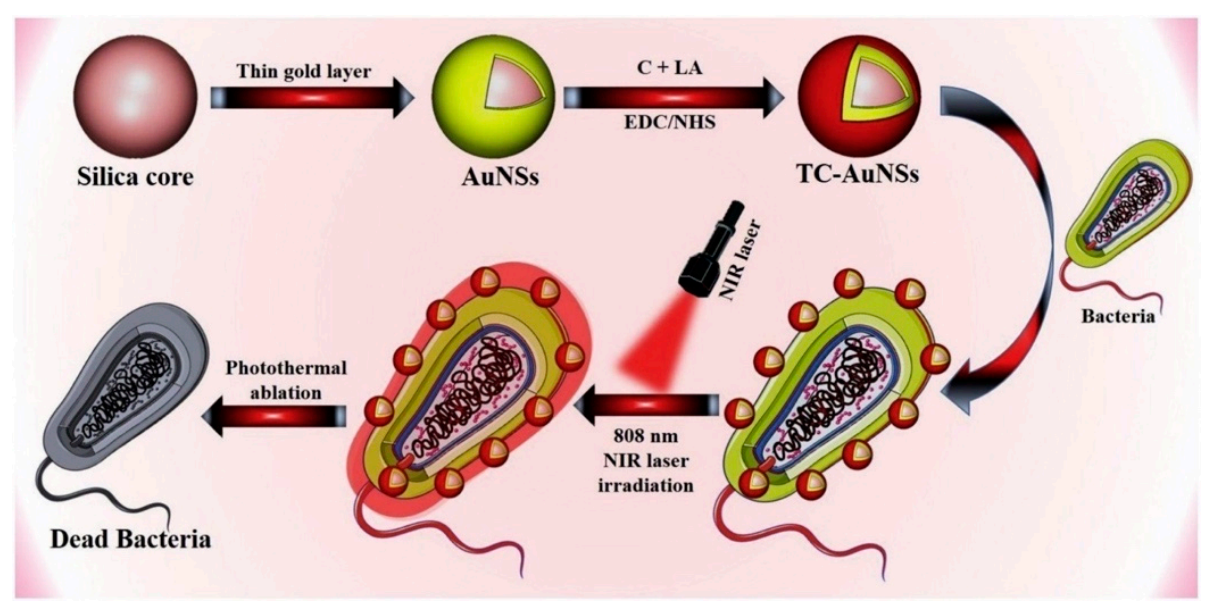

Figure 13. General representation of the photothermal mechanism for bacteria. Reproduced from [106], with permission from Elsevier, 2019.

In recent studies, the oligomer, OF GREEN N, has shown an enhanced photothermal efficiency of $37.7 \%$. The OF GREEN N oligomer displayed enhanced antibacterial activity against S. aureus under NIR laser irradiation [113]. Pegylated and thiolated (PEG-SH) gold nanorods (AuNRs) conjugated with a phospholipid (DSPE-AuNR-PEG-SH) and cholesterol (Chol-AuNR-PEG-SH) exhibited an antibacterial effect. The DSPE-AuNR-PEG-SH with NIR light irradiation did not demonstrate a significant increase in temperature. However, the Chol-AuNR-PEG-SH showed a significant increase in temperature of $19.7^{\circ} \mathrm{C}$ at $15 \mathrm{~min}$ under NIR light irradiation. The Chol-AuNR-PEG-SH displayed a bactericidal effect under NIR light irradiation against one of the ESKAPE pathogens. For obtaining a better photothermal efficiency, there should be adequate adhesion of the NPs to the target cell, tissue, or organ, which was found to be significantly low in the case of DSPE-AuNR-PEG-SH. The Chol-AuNR-PEG-SH was found to exhibit antibacterial activity, perhaps because there was significant adhesion of the NPs to the target skin tissue under NIR light irradiation [114,115].

Recently, there have been studies conducted to counter resistant biofilms using hydrogels and phospholipid-conjugated gold nanorods (DSPE-AuNR/hydrogels). In one study, researchers compared pulsed and continuous NIR laser beams on DSPE-AuNR/hydrogels for $15 \mathrm{~min}$. The percentage and average log reductions of viable bacteria counts were calculated. The DSPE-AuNR/hydrogel was found to be more effective against $P$. aeruginosa biofilms incubated for $72 \mathrm{~h}$ and treated with pulsed NIR beams for $15 \mathrm{~min}$ (Figure 14). The pulsed NIR laser would be less cell destructive and cause less harm to normal, surrounding cells. The bacterial biofilm used in that study was photothermally deactivated with a temperature increase of $50 \sim 80^{\circ} \mathrm{C}$ for more than $1 \mathrm{~h}$. The DSPE-GNR/hydrogel showed enhanced 
antibacterial activity under pulsed NIR irradiation for $15 \mathrm{~min}$. Additionally, the antibacterial activity of this polymer-based nanomaterial was confirmed by transmission electronic microscopy (TEM) and fluorescent microscopy [116-125].

\begin{tabular}{|c|c|c|}
\hline $\begin{array}{c}\text { Treatment } \\
\text { (Bacterial Biofilm } 72 \mathrm{hr} \text { ) }\end{array}$ & $\begin{array}{l}\text { Reduction of } \\
\text { Bacterial Viable Count } \\
(\%)\end{array}$ & $\begin{array}{c}\text { Average Log } \\
\text { Reduction }\end{array}$ \\
\hline DSPE-AuNR/0.25 nM & $78.0 \pm 16.2$ & 0.66 \\
\hline $\begin{array}{c}\text { DSPE-AuNR/0.25 nM } \\
\text { + Laser }\end{array}$ & $99.9997 \pm 0.0002$ & 5.52 \\
\hline DSPE-AuNR/0.125 nM & $69.45 \pm 30.0$ & 0.51 \\
\hline $\begin{array}{c}\text { DSPE-AuNR/0.125 nM } \\
+ \text { + Laser }\end{array}$ & $99.71 \pm 0.27$ & 2.52 \\
\hline DSPE-AuNR/0.06 nM & $45.78 \pm 20.2$ & 0.26 \\
\hline $\begin{array}{c}\text { DSPE-AuNR/0.06 nM } \\
\text { + Laser }\end{array}$ & $99.81 \pm 0.30$ & 2.69 \\
\hline Laser & $54.82 \pm 12.0$ & 0.34 \\
\hline
\end{tabular}

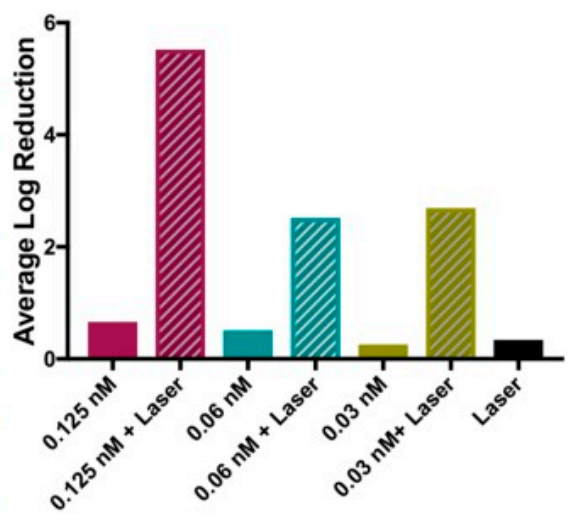

Figure 14. Antibacterial activity under NIR laser light by a phospholipid-conjugated gold nanorods (DSPE-AuNR) suspension loaded into a poloxamer 407 hydrogel against P. aeruginosa biofilm (72 h) using a continuous wave $(\mathrm{CW})$ or pulsed laser at 3 and $1 \mathrm{~W} / \mathrm{cm}^{2}$. (Left) Calculation of the percentage reductions in viable bacteria counts with AuNR/hydrogel after NIR laser excitation (CW vs. pulsed) and in dark conditions. (Right) Calculation of the average log reductions of viable bacterial counts after treatment with AuNR/hydrogel and NIR laser excitation (CW vs. pulsed) and under dark conditions. Reproduced from [116], with permission from MDPI, 2019.

In this review, for investigating the optical properties of nanomaterials, it can be seen that metal-, carbon-, and polymer-based nanomaterials have been designed to absorb NIR light, and NIR light energy has then been transformed into heat for the photothermal killing of bacteria. Moreover, in terms of the photothermal efficiencies of nanomaterials, the solutions of metal-, carbon-, and polymer-based nanomaterials have shown capabilities with respect to increases of their temperatures, including 46, 40 , and $58{ }^{\circ} \mathrm{C}$, respectively. The solutions of metal-, carbon-, and polymer-based nanomaterials can be separately heated to $65.3,60$, and $78{ }^{\circ} \mathrm{C}$. Previous studies have reported that NIR light-induced photothermal therapy generally requires hyperthermic temperatures $\left(>43^{\circ} \mathrm{C}\right)$ for the effective killing of bacteria or cancer cells [126]. In sum, the photothermal efficiencies of nanomaterials selected in this review have exhibited superior antibacterial activities.

\section{Discussion}

We have summarized papers with a detailed introduction on treatments of bacterial focal infections utilizing PTT by nanomaterials in this review (Table 1). The works we have described have demonstrated the ability of different nanomaterials to kill bacteria by up to $99.99 \%$ in vitro and in vivo with photothermal techniques. As a general trend, the photothermal antibacterial effects of composites of metal, carbon, and polymers turned out to be better than those of the same materials used alone. In addition to generating heat, the composites can provide certain properties, such as enzymatic activity (DNase, protease), ROS generation, enhanced ion release (silver ions), and electrostatic attraction between surface charges of the composite and cell wall charges of the bacteria. These properties are favorable for bacterial destruction and improve the antibacterial effect when they are associated with PTT. Another perspective to encourage in PTT research for bacterial killing is the combination of PTT with other techniques, namely photodynamic and gene therapies, for producing synergistic antibacterial effects. The combination of PTT with different techniques can also avoid the use of very high temperatures, which is toxic to surrounding cells and remains one of the important challenges of PTT. 
Table 1. Comparison of nanomaterials with photothermal effects as antibacterial agents.

\begin{tabular}{|c|c|c|c|c|c|c|}
\hline $\begin{array}{l}\text { Nanomaterial } \\
\text { Types }\end{array}$ & $\begin{array}{c}\text { Nanomaterials and } \\
\text { Sizes }\end{array}$ & $\begin{array}{l}\text { Antibacterial } \\
\text { Mechanisms }\end{array}$ & $\begin{array}{c}\text { Laser } \\
\text { Wavelengths } \\
\text { Laser Intensities } \\
\text { Irradiation Time }\end{array}$ & $\begin{array}{l}\text { Bacterial } \\
\text { Strains }\end{array}$ & $\begin{array}{c}\text { In Vitro } \\
\text { and In Vivo }\end{array}$ & Ref. \\
\hline \multirow{3}{*}{$\begin{array}{c}\text { Metal-based } \\
\text { nanomaterials }\end{array}$} & $\begin{array}{l}\text { AuNWs } \\
5 \pm 1.5 \mathrm{~nm}\end{array}$ & PTT & $\begin{array}{c}808 \mathrm{~nm} \\
1 \mathrm{~W} / \mathrm{cm}^{2} \\
20 \mathrm{~min}\end{array}$ & $\begin{array}{l}\text { E. coli } \\
\text { S. aureus }\end{array}$ & In vitro & [39] \\
\hline & $\begin{array}{l}\text { MPPI NSs } \\
100 \sim 500 \mathrm{~nm}\end{array}$ & $\begin{array}{c}\text { PTT and } \\
\text { affinity of bacteria } \\
\text { and nanomaterial }\end{array}$ & $\begin{array}{c}785 \mathrm{~nm} \\
0.58 \mathrm{~W} / \mathrm{cm}^{2} \\
10 \mathrm{~min}\end{array}$ & $\begin{array}{c}\text { S. aureus } \\
\text { P. aeruginosa }\end{array}$ & $\begin{array}{l}\text { In vitro and } \\
\text { in vivo }\end{array}$ & [42] \\
\hline & $\begin{array}{l}\text { DNase-AuNCs } \\
2.33 \pm 0.72 \mathrm{~nm}\end{array}$ & $\begin{array}{c}\text { PTT and } \\
\text { PDT and } \\
\text { DNase activity }\end{array}$ & $\begin{array}{c}808 \mathrm{~nm} \\
2 \mathrm{~W} / \mathrm{cm}^{2} \\
10 \mathrm{~min}\end{array}$ & $\begin{array}{l}\text { MDR GPB and } \\
\text { GNB }\end{array}$ & In vitro & [59] \\
\hline \multirow[b]{2}{*}{$\begin{array}{l}\text { Carbon-based } \\
\text { nanomaterials }\end{array}$} & $\begin{array}{l}\text { RP/GO film } \\
0.65 \mu \mathrm{m}\end{array}$ & PTT & $\begin{array}{c}\text { SSL and } 808 \mathrm{~nm} \\
0.2 \text { and } 0.6 \mathrm{~W} / \mathrm{cm}^{2} \\
20 \mathrm{~min}\end{array}$ & $\begin{array}{l}\text { E. coli } \\
\text { S. aureus }\end{array}$ & In vitro & [60] \\
\hline & $\begin{array}{l}\text { GA-Ag NPs } \\
43.1 \mathrm{~nm}\end{array}$ & PTT & $\begin{array}{c}808 \mathrm{~nm} \\
2 \mathrm{~W} / \mathrm{cm}^{2} \\
10 \mathrm{~min}\end{array}$ & $\begin{array}{l}\text { E. coli } \\
\text { S. aureus }\end{array}$ & $\begin{array}{l}\text { In vitro } \\
\text { and in vivo }\end{array}$ & [61] \\
\hline \multirow{4}{*}{$\begin{array}{l}\text { Polymer-based } \\
\text { nanomaterials }\end{array}$} & $\begin{array}{l}\text { ATF hydrogel } \\
30 \times 4 \mathrm{~mm}\end{array}$ & PTT & $\begin{array}{c}808 \mathrm{~nm} \\
1 \mathrm{~W} / \mathrm{cm}^{2} \\
10 \mathrm{~min}\end{array}$ & S. aureus & $\begin{array}{l}\text { In vitro and } \\
\text { in vivo }\end{array}$ & [92] \\
\hline & $\begin{array}{l}\text { PU-Au-PEG } \\
40 \times 10 \mathrm{~nm}\end{array}$ & $\begin{array}{l}\text { PTT andpolymer } \\
\text { bed }\end{array}$ & $\begin{array}{l}808 \mathrm{~nm} \\
1.2 \mathrm{~W} / \mathrm{cm}^{2} \\
3 \mathrm{~min}\end{array}$ & $\begin{array}{l}\text { P. aeruginosa } \\
\text { S. aureus }\end{array}$ & $\begin{array}{l}\text { In vitro and } \\
\text { in vivo }\end{array}$ & [96] \\
\hline & $\begin{array}{c}\text { TC-AuNSs } \\
\text { Average diameter of } \\
120 \mathrm{~nm}\end{array}$ & PTT & $\begin{array}{c}808 \mathrm{~nm} \\
0.95 \mathrm{~W} / \mathrm{cm}^{2} \\
5 \mathrm{~min}\end{array}$ & $\begin{array}{c}\text { S. aureus, } \\
\text { P. aeruginosa }\end{array}$ & In vitro & [106] \\
\hline & $\begin{array}{c}\text { DSPE/AuNR } \\
49.8 \pm 2.6 \times 11.8 \pm \\
1.8 \mathrm{~nm}\end{array}$ & PTT & $\begin{array}{c}808 \mathrm{~nm} \\
3 \mathrm{~W} / \mathrm{cm}^{2} \\
15 \mathrm{~min}\end{array}$ & P. aeruginosa & In vitro & [116] \\
\hline
\end{tabular}

Abbreviations: AuNWs: gold nanoworms; PGs: protease-conjugated gold nanorods; MPPI NSs: MoS 2 -coated PDA, PEG-SH, and IgG nanosheets; Au-Ag@SiO 2 NCs: silica-coated gold-silver nanocages; Ti-GNRs: gold nanorods coated on titanium; DNase-AuNCs: gold nanoclusters coated with DNase; RP/GO: graphene oxide coated on red phosphorous; GA-Ag NPs: gallic acid-conjugated silver nanoparticles; RGO/Ag: silver nanoparticles embedded in reduced graphene oxide; GNRs; graphene nanoribbons; ATF: Ta-Fe composite; PU-Au-PEG: polyurethane-conjugated gold nanorods coated with PEG (PU-Au-PEG); TC-AuNSs: thiol-chitosan gold nanoshells; DSPE/AuNR/hydrogel: hydrogel and phospholipid-conjugated gold nanorod; PTT: photothermal therapy; PDT: photodynamic therapy; SSL: simulated sunlight; MDR: multidrug-resistant; GPB: gram-positive bacteria; GNB: gram-negative bacteria.

Funding: This work was financially supported by MOST 108-2113-M-038-003, Taipei Medical University and the Higher Education Sprout Project by the Ministry of Education (MOE) in Taiwan.

Conflicts of Interest: The authors declare no conflict of interest. 


\section{References}

1. Neu, H.C. The crisis in antibiotic-resistance. Science 1992, 257, 1064-1073. [CrossRef] [PubMed]

2. Levy, S.B.; Marshall, B. Antibacterial resistance worldwide: Causes, challenges and responses. Nat. Med. 2004, 10, S122-S129. [CrossRef] [PubMed]

3. Kumarasamy, K.K.; Toleman, M.A.; Walsh, T.R.; Bagaria, J.; Butt, F.; Balakrishnan, R.; Chaudhary, U.; Doumith, M.; Giske, C.G.; Irfan, S.; et al. Emergence of a new antibiotic resistance mechanism in india, pakistan, and the uk: A molecular, biological, and epidemiological study. Lancet. Infect. Dis. 2010, 10, 597-602. [CrossRef]

4. Panacek, A.; Kvitek, L.; Smekalova, M.; Vecerova, R.; Kolar, M.; Roderova, M.; Dycka, F.; Sebela, M.; Prucek, R.; Tomanec, O.; et al. Bacterial resistance to silver nanoparticles and how to overcome it. Nat. Nanotechnol. 2018, 13, 65-71. [CrossRef] [PubMed]

5. Chang, Y.; Chusri, S.; Sangthong, R.; McNeil, E.; Hu, J.; Du, W.; Li, D.; Fan, X.; Zhou, H.; Chongsuvivatwong, V.; et al. Clinical pattern of antibiotic overuse and misuse in primary healthcare hospitals in the southwest of china. PLoS ONE 2019, 14, e0214779. [CrossRef] [PubMed]

6. Duncan, B.; Li, X.; Landis, R.F.; Kim, S.T.; Gupta, A.; Wang, L.-S.; Ramanathan, R.; Tang, R.; Boerth, J.A.; Rotello, V.M. Nanoparticle-stabilized capsules for the treatment of bacterial biofilms. ACS Nano 2015, 9, 7775-7782. [CrossRef]

7. Liu, G.; Zou, J.; Tang, Q.; Yang, X.; Zhang, Y.; Zhang, Q.; Huang, W.; Chen, P.; Shao, J.; Dong, X. Surface modified ti3c2 mxene nanosheets for tumor targeting photothermal/photodynamic/chemo synergistic therapy. ACS Appl. Mater. Interfaces 2017, 9, 40077-40086. [CrossRef]

8. Han, D.L.; Han, Y.J.; Li, J.; Liu, X.M.; Yeung, K.W.K.; Zheng, Y.F.; Cui, Z.D.; Yang, X.J.; Liang, Y.Q.; Li, Z.Y.; et al. Enhanced photocatalytic activity and photothermal effects of cu-doped metal-organic frameworks for rapid treatment of bacteria-infected wounds. Appl. Catal. B-Environ. 2020, 261, 118248. [CrossRef]

9. Ray, P.C.; Khan, S.A.; Singh, A.K.; Senapati, D.; Fan, Z. Nanomaterials for targeted detection and photothermal killing of bacteria. Chem. Soc. Rev. 2012, 41, 3193-3209. [CrossRef]

10. Chiang, C.W.; Chuang, E.Y. Biofunctional core-shell polypyrrole-polyethylenimine nanocomplex for a locally sustained photothermal with reactive oxygen species enhanced therapeutic effect against lung cancer. Int. J. Nanomed. 2019, 14, 1575-1585. [CrossRef]

11. Burnouf, T.; Chen, C.H.; Tan, S.J.; Tseng, C.L.; Lu, K.Y.; Chang, L.H.; Nyambat, B.; Huang, S.C.; Jheng, P.R.; Aditya, R.N.; et al. A bioinspired hyperthermic macrophage-based polypyrrole-polyethylenimine (ppy-pei) nanocomplex carrier to prevent and disrupt thrombotic fibrin clots. Acta Biomater. 2019, 96, 468-479. [CrossRef] [PubMed]

12. Satapathy, M.K.; Nyambat, B.; Chiang, C.W.; Chen, C.H.; Wong, P.C.; Ho, P.H.; Jheng, P.R.; Burnouf, T.; Tseng, C.L.; Chuang, E.Y. A gelatin hydrogel-containing nano-organic pei-ppy with a photothermal responsive effect for tissue engineering applications. Molecules 2018, 23, 1256. [CrossRef] [PubMed]

13. Mi, F.L.; Burnouf, T.; Lu, S.Y.; Lu, Y.J.; Lu, K.Y.; Ho, Y.C.; Kuo, C.Y.; Chuang, E.Y. Self-targeting, immune transparent plasma protein coated nanocomplex for noninvasive photothermal anticancer therapy. Adv. Healthc. Mater. 2017, 6. [CrossRef]

14. Jheng, P.R.; Lu, K.Y.; Yu, S.H.; Mi, F.L. Free dox and chitosan-n-arginine conjugate stabilized indocyanine green nanoparticles for combined chemophotothermal therapy. Colloids and surfaces. B 2015, 136, 402-412. [CrossRef] [PubMed]

15. Jain, P.K.; Lee, K.S.; El-Sayed, I.H.; El-Sayed, M.A. Calculated absorption and scattering properties of gold nanoparticles of different size, shape, and composition: Applications in biological imaging and biomedicine. J. Phys. Chem. B 2006, 110, 7238-7248. [CrossRef] [PubMed]

16. Xu, J.-W.; Yao, K.; Xu, Z.-K. Nanomaterials with a photothermal effect for antibacterial activities: An overview. Nanoscale 2019, 11, 8680-8691. [CrossRef]

17. Annesi, F.; Pane, A.; Losso, M.A.; Guglielmelli, A.; Lucente, F.; Petronella, F.; Placido, T.; Comparelli, R.; Guzzo, M.G.; Curri, M.L. Thermo-plasmonic killing of escherichia coli tg1 bacteria. Materials 2019, 12, 1530. [CrossRef]

18. Teng, C.P.; Zhou, T.; Ye, E.; Liu, S.; Koh, L.D.; Low, M.; Loh, X.J.; Win, K.Y.; Zhang, L.; Han, M.Y. Effective targeted photothermal ablation of multidrug resistant bacteria and their biofilms with NIR-absorbing gold nanocrosses. Adv. Healthc. Mater. 2016, 5, 2122-2130. [CrossRef] 
19. Wang, J.; Zhang, Y.; Liu, L.; Cui, Z.; Liu, X.; Wang, L.; Li, Y.; Li, Q. Combined chemo/photothermal therapy based on mesoporous silica-au core-shell nanoparticles for hepatocellular carcinoma treatment. Drug Dev. Ind. Pharm. 2019, 45, 1487-1495. [CrossRef]

20. De Angelis, B.; Depalo, N.; Petronella, F.; Quintarelli, C.; Curri, M.L.; Pani, R.; Calogero, A.; Locatelli, F.; De Sio, L. Stimuli-responsive nanoparticle-assisted immunotherapy: A new weapon against solid tumours. J. Mater. Chem. B 2020, 8, 1823-1840. [CrossRef]

21. Caló, E.; Khutoryanskiy, V.V. Biomedical applications of hydrogels: A review of patents and commercial products. Eur. Polym. J. 2015, 65, 252-267. [CrossRef]

22. Cheng, C.H.; Lin, K.J.; Hong, C.T.; Wu, D.; Chang, H.M.; Liu, C.H.; Hsiao, I.T.; Yang, C.P.; Liu, Y.C.; Hu, C.J. Plasmon-activated water reduces amyloid burden and improves memory in animals with alzheimer's disease. Sci. Rep. 2019, 9. [CrossRef] [PubMed]

23. Yang, C.P.; Fang, S.U.; Tsai, H.Y.; Chen, J.W.; Liu, Y.C. Newly prepared surface-enhanced raman scattering-active substrates for sensing pesticides. J. Electroanal. Chem. 2020, 861. [CrossRef]

24. Hung, W.H.; Zheng, J.H.; Lee, K.C.; Cho, E.C. Doxorubicin conjugated aunp/biopolymer composites facilitate cell cycle regulation and exhibit superior tumor suppression potential in kras mutant colorectal cancer. J. Biotechnol. 2019, 306, 149-158. [CrossRef] [PubMed]

25. Chuang, C.S.; Wu, C.Y.; Juan, P.H.; Hou, N.C.; Fan, Y.J.; Wei, P.K.; Sheen, H.J. Lmp1 gene detection using a capped gold nanowire array surface plasmon resonance sensor in a microfluidic chip. Analyst 2020, 145, 52-60. [CrossRef] [PubMed]

26. Ye, X.; Zheng, C.; Chen, J.; Gao, Y.; Murray, C.B. Using binary surfactant mixtures to simultaneously improve the dimensional tunability and monodispersity in the seeded growth of gold nanorods. Nano Lett. 2013, 13, 765-771. [CrossRef] [PubMed]

27. Quyen, T.T.B.; Chang, C.C.; Su, W.N.; Uen, Y.H.; Pan, C.J.; Liu, J.Y.; Rick, J.; Lin, K.Y.; Hwang, B.J. Self-focusing au@sio2 nanorods with rhodamine $6 \mathrm{~g}$ as highly sensitive sers substrate for carcinoembryonic antigen detection. J. Mater. Chem. B 2014, 2, 629-636. [CrossRef] [PubMed]

28. Liao, Y.T.; Liu, C.H.; Chin, Y.; Chen, S.Y.; Liu, S.H.; Hsu, Y.C.; Wu, K.C.W. Biocompatible and multifunctional gold nanorods for effective photothermal therapy of oral squamous cell carcinoma. J. Mater. Chem. B 2019, 7, 4451-4460. [CrossRef]

29. Liu, X.-L.; Wang, J.-H.; Liang, S.; Yang, D.-J.; Nan, F.; Ding, S.-J.; Zhou, L.; Hao, Z.-H.; Wang, Q.-Q. Tuning plasmon resonance of gold nanostars for enhancements of nonlinear optical response and raman scattering. J. Phys. Chem. C 2014, 118, 9659-9664. [CrossRef]

30. Navarro, J.R.; Manchon, D.; Lerouge, F.; Cottancin, E.; Lerme, J.; Bonnet, C.; Chaput, F.; Mosset, A.; Pellarin, M.; Parola, S. Synthesis, electron tomography and single-particle optical response of twisted gold nano-bipyramids. Nanotechnology 2012, 23, 145707. [CrossRef]

31. Murph, S.E.H.; Murphy, C.J.; Leach, A.; Gall, K. A possible oriented attachment growth mechanism for silver nanowire formation. Cryst. Growth Des. 2015, 15, 1968-1974. [CrossRef]

32. Wu, C.Y.; Cheng, H.Y.; Ou, K.L.; Wu, C.C. Real-time sensing of hepatitis $b$ virus $x$ gene using an ultrasensitive nanowire field effect transistor. J. Polym. Eng. 2014, 34, 273-277. [CrossRef]

33. Wu, C.C.; Liu, F.K.; Lin, L.H.; Pang, S.T.; Chuang, C.K.; Pan, T.M.; Ou, K.L.; Ko, F.H. Surface cleaning of the nanowire field-effect transistor for gene detection. J. Nanosci. Nanotechnol. 2011, 11, 10639-10643. [CrossRef] [PubMed]

34. Jang, H.; Kim, Y.K.; Min, D.H. Synthesis of partially dextran-coated gold nanoworms and anisotropic structure based dual-strategic cargo conjugation for efficient combinational cancer therapy. Chem. Commun. 2017, 53, 1385-1388. [CrossRef]

35. Choi, C.K.K.; Chiu, Y.T.E.; Zhuo, X.; Liu, Y.; Pak, C.Y.; Liu, X.; Tse, Y.S.; Wang, J.; Choi, C.H.J. Dopaminemediated assembly of citrate-capped plasmonic nanoparticles into stable core-shell nanoworms for intracellular applications. ACS Nano 2019, 13, 5864-5884. [CrossRef]

36. Khan, H.I.; Khan, G.A.; Mehmood, S.; Khan, A.D.; Ahmed, W. Gold nanoworms: Optical properties and simultaneous sers and fluorescence enhancement. Spectrochim. Acta A 2019, 220, 117111. [CrossRef]

37. Jena, B.K.; Raj, C.R. Seedless, surfactantless room temperature synthesis of single crystalline fluorescent gold nanoflowers with pronounced sers and electrocatalytic activity. Chem. Mater. 2008, 20, 3546-3548. [CrossRef] 
38. Wang, L.; Liu, C.H.; Nemoto, Y.; Fukata, N.; Wu, K.C.W.; Yamauchi, Y. Rapid synthesis of biocompatible gold nanoflowers with tailored surface textures with the assistance of amino acid molecules. RSC Adv. 2012, 2, 4608-4611. [CrossRef]

39. Liao, Z.; Zhang, W.; Qiao, Z.; Luo, J.; Ai Niwaer, A.E.; Meng, X.; Wang, H.; Li, X.; Zuo, F.; Zhao, Z. Dopamine-assisted one-pot synthesis of gold nanoworms and their application as photothermal agents. J. Colloid Interface Sci. 2020, 562, 81-90. [CrossRef]

40. Li, W.; Geng, X.; Liu, D.; Li, Z. Near-infrared light-enhanced protease-conjugated gold nanorods as a photothermal antimicrobial agent for elimination of exotoxin and biofilms. Int. J. Nanomed. 2019, 14, 8047-8058. [CrossRef]

41. Yuwen, L.; Sun, Y.; Tan, G.; Xiu, W.; Zhang, Y.; Weng, L.; Teng, Z.; Wang, L. Mos2@polydopamine-ag nanosheets with enhanced antibacterial activity for effective treatment of staphylococcus aureus biofilms and wound infection. Nanoscale 2018, 10, 16711-16720. [CrossRef] [PubMed]

42. Zhang, Y.; Xiu, W.; Gan, S.; Shan, J.; Ren, S.; Yuwen, L.; Weng, L.; Teng, Z.; Wang, L. Antibody-functionalized mos2 nanosheets for targeted photothermal therapy of staphylococcus aureus focal infection. Front. Bioeng. Biotechnol. 2019, 7, 218. [CrossRef] [PubMed]

43. Fasciani, C.; Silvero, M.J.; Anghel, M.A.; Argüello, G.A.; Becerra, M.C.; Scaiano, J.C. Aspartame-stabilized gold-silver bimetallic biocompatible nanostructures with plasmonic photothermal properties, antibacterial activity, and long-term stability. J. Am. Chem. Soc. 2014, 136, 17394-17397. [CrossRef] [PubMed]

44. Khlebtsov, B.N.; Khanadeev, V.A.; Maksimova, I.L.; Terentyuk, G.S.; Khlebtsov, N.G. Silver nanocubes and gold nanocages: Fabrication and optical and photothermal properties. Nanotechnol. Russ. 2010, 5, 454-468. [CrossRef]

45. Wang, C.; Wang, Y.; Zhang, L.; Miron, R.J.; Liang, J.; Shi, M.; Mo, W.; Zheng, S.; Zhao, Y.; Zhang, Y. Pretreated macrophage-membrane-coated gold nanocages for precise drug delivery for treatment of bacterial infections. Adv. Mater. 2018, 30, 1804023. [CrossRef]

46. Wu, S.; Li, A.; Zhao, X.; Zhang, C.; Yu, B.; Zhao, N.; Xu, F.-J. Silica coated gold-silver nanocages as photothermal antibacterial agents for combined anti-infective therapy. ACS Appl. Mater. Interfaces 2019. [CrossRef]

47. Ronald, A. The etiology of urinary tract infection: Traditional and emerging pathogens. Am. J. Med. 2002, 113, 14-19. [CrossRef]

48. Wang, Y.; Wan, J.; Miron, R.J.; Zhao, Y.; Zhang, Y. Antibacterial properties and mechanisms of gold-silver nanocages. Nanoscale 2016, 8, 11143-11152. [CrossRef]

49. Gupta, K.; Singh, R.; Pandey, A.; Pandey, A. Photocatalytic antibacterial performance of $\mathrm{TiO}_{2}$ and ag-doped $\mathrm{TiO}_{2}$ against s. Aureus. P. Aeruginosa and e. Coli. Beilstein J. Nanotechnol. 2013, 4, 345-351. [CrossRef]

50. Arunachalam, A.; Dhanapandian, S.; Manoharan, C.; Sivakumar, G. Physical properties of Zn doped TiO thin films with spray pyrolysis technique and its effects in antibacterial activity. Spectrochim. Acta A 2015, 138, 105-112. [CrossRef]

51. He, W.; Huang, H.; Yan, J.; Zhu, J. Photocatalytic and antibacterial properties of Au- $\mathrm{TiO}_{2}$ nanocomposite on monolayer graphene: From experiment to theory. J. Appl. Phys. 2013, 114, 204701. [CrossRef]

52. Yang, T.; Wang, D.; Liu, X. Assembled gold nanorods for the photothermal killing of bacteria. Colloids Surf. $B$ 2019, 173, 833-841. [CrossRef] [PubMed]

53. Spengler, C.; Thewes, N.; Jung, P.; Bischoff, M.; Jacobs, K. Determination of the nano-scaled contact area of staphylococcal cells. Nanoscale 2017, 9, 10084-10093. [CrossRef] [PubMed]

54. Gu, J.; Valdevit, A.; Chou, T.-M.; Libera, M. Substrate effects on cell-envelope deformation during early-stage staphylococcus aureus biofilm formation. Soft Matter 2017, 13, 2967-2976. [CrossRef] [PubMed]

55. Fitzpatrick, P.F. Substrate dehydrogenation by flavoproteins. Acc. Chem. Res. 2001, 34, 299-307. [CrossRef]

56. Chen, J.; Wang, D.; Xi, J.; Au, L.; Siekkinen, A.; Warsen, A.; Li, Z.-Y.; Zhang, H.; Xia, Y.; Li, X. Immuno gold nanocages with tailored optical properties for targeted photothermal destruction of cancer cells. Nano Lett. 2007, 7, 1318-1322. [CrossRef] [PubMed]

57. Gobin, A.M.; Lee, M.H.; Halas, N.J.; James, W.D.; Drezek, R.A.; West, J.L. Near-infrared resonant nanoshells for combined optical imaging and photothermal cancer therapy. Nano lett. 2007, 7, 1929-1934. [CrossRef]

58. Zhu, X.-M.; Fang, C.; Jia, H.; Huang, Y.; Cheng, C.H.; Ko, C.-H.; Chen, Z.; Wang, J.; Wang, Y.-X.J. Cellular uptake behaviour, photothermal therapy performance, and cytotoxicity of gold nanorods with various coatings. Nanoscale 2014, 6, 11462-11472. [CrossRef] 
59. Xie, Y.; Zheng, W.; Jiang, X. Near-infrared light-activated phototherapy by gold nanoclusters for dispersing biofilms. ACS Appl. Mater. Interfaces 2020, 12, 9041-9049. [CrossRef]

60. Zhang, Q.; Liu, X.; Tan, L.; Cui, Z.; Li, Z.; Liang, Y.; Zhu, S.; Yeung, K.; Zheng, Y.; Wu, S. An UV to NIR-driven platform based on red phosphorus/graphene oxide film for rapid microbial inactivation. Chem. Eng. J. 2020, 383, 123088. [CrossRef]

61. Liu, Y.; Li, F.; Guo, Z.; Xiao, Y.; Zhang, Y.; Sun, X.; Zhe, T.; Cao, Y.; Wang, L.; Lu, Q. Silver nanoparticleembedded hydrogel as a photothermal platform for combating bacterial infections. Chem. Eng. J. 2020, 382, 122990. [CrossRef]

62. Qiao, Y.; Ma, F.; Liu, C.; Zhou, B.; Wei, Q.; Li, W.; Zhong, D.; Li, Y.; Zhou, M. Near-infrared laser-excited nanoparticles to eradicate multidrug-resistant bacteria and promote wound healing. ACS Appl. Mater. Interfaces 2018, 10, 193-206. [CrossRef] [PubMed]

63. Huang, J.; Zhou, J.; Zhuang, J.; Gao, H.; Huang, D.; Wang, L.; Wu, W.; Li, Q.; Yang, D.-P.; Han, M.-Y. Strong near-infrared absorbing and biocompatible CuS nanoparticles for rapid and efficient photothermal ablation of gram-positive and -negative bacteria. ACS Appl. Mater. Interfaces 2017, 9, 36606-36614. [CrossRef] [PubMed]

64. Liu, Z.; Liu, X.; Du, Y.; Ren, J.; Qu, X. Using plasmonic copper sulfide nanocrystals as smart light-driven sterilants. ACS Nano 2015, 9, 10335-10346. [CrossRef]

65. Gao, Q.; Zhang, X.; Yin, W.; Ma, D.; Xie, C.; Zheng, L.; Dong, X.; Mei, L.; Yu, J.; Wang, C. Functionalized $\mathrm{MoS}_{2}$ nanovehicle with near-infrared laser-mediated nitric oxide release and photothermal activities for advanced bacteria-infected wound therapy. Small 2018, 14, 1802290. [CrossRef]

66. Jia, X.; Ahmad, I.; Yang, R.; Wang, C. Versatile graphene-based photothermal nanocomposites for effectively capturing and killing bacteria, and for destroying bacterial biofilms. J. Mater. Chem. B 2017, 5, 2459-2467. [CrossRef]

67. Agnihotri, S.; Mukherji, S.; Mukherji, S. Impact of background water quality on disinfection performance and silver release of immobilized silver nanoparticles: Modeling disinfection kinetics, bactericidal mechanism and aggregation behavior. Chem. Eng. J. 2019, 372, 684-696. [CrossRef]

68. Zhou, C.; Wang, F.; Chen, H.; Li, M.; Qiao, F.; Liu, Z.; Hou, Y.; Wu, C.; Fan, Y.; Liu, L.; et al. Selective antimicrobial activities and action mechanism of micelles self-assembled by cationic oligomeric surfactants. ACS Appl. Mater. Interfaces 2016, 8, 4242-4249. [CrossRef]

69. Li, S.; Wang, X.; Hu, R.; Chen, H.; Li, M.; Wang, J.; Wang, Y.; Liu, L.; Lv, F.; Liang, X.-J.; et al. Near-infrared (NIR)-absorbing conjugated polymer dots as highly effective photothermal materials for in vivo cancer therapy. Chem. Mater. 2016, 28, 8669-8675. [CrossRef]

70. Lim, D.-K.; Barhoumi, A.; Wylie, R.G.; Reznor, G.; Langer, R.S.; Kohane, D.S. Enhanced photothermal effect of plasmonic nanoparticles coated with reduced graphene oxide. Nano Lett. 2013, 13, 4075-4079. [CrossRef]

71. Wu, M.-C.; Deokar, A.R.; Liao, J.-H.; Shih, P.-Y.; Ling, Y.-C. Graphene-based photothermal agent for rapid and effective killing of bacteria. ACS Nano 2013, 7, 1281-1290. [CrossRef]

72. Yang, F.; Feng, Y.; Fan, X.; Zhang, M.; Wang, C.; Zhao, W.; Zhao, C. Biocompatible graphene-based nanoagent with NIR and magnetism dual-responses for effective bacterial killing and removal. Colloids Surfaces B 2019, 173, 266-275. [CrossRef] [PubMed]

73. Tan, S.; Wu, X.; Xing, Y.; Lilak, S.; Wu, M.; Zhao, J.X. Enhanced synergetic antibacterial activity by a reduce graphene oxide/ag nanocomposite through the photothermal effect. Colloids Surfaces B 2020, 185, 110616. [CrossRef] [PubMed]

74. Robinson, J.T.; Tabakman, S.M.; Liang, Y.; Wang, H.; Sanchez Casalongue, H.; Vinh, D.; Dai, H. Ultrasmall reduced graphene oxide with high near-infrared absorbance for photothermal therapy. J. Am. Chem. Soc. 2011, 133, 6825-6831. [CrossRef] [PubMed]

75. Akhavan, O.; Ghaderi, E.; Aghayee, S.; Fereydooni, Y.; Talebi, A. The use of a glucose-reduced graphene oxide suspension for photothermal cancer therapy. J. Mater. Chem. 2012, 22, 13773-13781. [CrossRef]

76. Sheng, Z.; Song, L.; Zheng, J.; Hu, D.; He, M.; Zheng, M.; Gao, G.; Gong, P.; Zhang, P.; Ma, Y. Protein-assisted fabrication of nano-reduced graphene oxide for combined in vivo photoacoustic imaging and photothermal therapy. Biomaterials 2013, 34, 5236-5243. [CrossRef]

77. Wang, S.-G.; Chen, Y.-C.; Chen, Y.-C. Antibacterial gold nanoparticle-based photothermal killing of vancomycin-resistant bacteria. Nanomedicine 2018, 13, 1405-1416. [CrossRef] 
78. Yu, Z.H.; Li, X.; Xu, F.; Hu, X.L.; Yan, J.; Kwon, N.; Chen, G.R.; Tang, T.; Dong, X.; Mai, Y.; et al. A supramolecular-based dual-wavelength phototherapeutic agent with broad-spectrum antimicrobial activity against drug-resistant bacteria. Angew. Chem. Int. Ed. Engl. 2020, 59, 3658-3664. [CrossRef]

79. Ghobril, C.; Grinstaff, M.W. The chemistry and engineering of polymeric hydrogel adhesives for wound closure: A tutorial. Chem. Soc. Rev. 2015, 44, 1820-1835. [CrossRef]

80. Su, C.Y.; Ho, H.O.; Chen, Y.C.; Yu, Y.T.; Liu, D.Z.; Chao, F.C.; Sheu, M.T. Complex hydrogels composed of chitosan with ring-opened polyvinyl pyrrolidone as a gastroretentive drug dosage form to enhance the bioavailability of bisphosphonates. Sci. Rep. 2018, 8. [CrossRef]

81. Yao, H.Y.; Lin, H.R.; Sue, G.P.; Lin, Y.J. Chitosan-based hydrogels prepared by UV polymerization for wound dressing. Polym. Compos. 2019, 27, 155-167. [CrossRef]

82. Huang, Y.M.; Lin, Y.C.; Chen, C.Y.; Hsieh, Y.Y.; Liaw, C.K.; Huang, S.W.; Tsuang, Y.H.; Chen, C.H.; Lin, F.H. Thermosensitive chitosan-gelatin-glycerol phosphate hydrogels as collagenase carrier for tendon-bone healing in a rabbit model. Polymers 2020, 12, 436. [CrossRef] [PubMed]

83. Lo, Y.W.; Sheu, M.T.; Chiang, W.H.; Chiu, Y.L.; Tu, C.M.; Wang, W.Y.; Wu, M.H.; Wang, Y.C.; Lu, M.; Ho, H.O. In situ chemically crosslinked injectable hydrogels for the subcutaneous delivery of trastuzumab to treat breast cancer. Acta Biomater. 2019, 86, 280-290. [CrossRef] [PubMed]

84. Tao, B.; Lin, C.; Deng, Y.; Yuan, Z.; Shen, X.; Chen, M.; He, Y.; Peng, Z.; Hu, Y.; Cai, K. Coppernanoparticle-embedded hydrogel for killing bacteria and promoting wound healing with photothermal therapy. J. Mater. Chem. B 2019, 7, 2534-2548. [CrossRef] [PubMed]

85. Kim, T.I.; Kim, J.; Park, I.-J.; Cho, K.-O.; Choi, S.-Y. Chemically exfoliated 1t-phase transition metal dichalcogenide nanosheets for transparent antibacterial applications. 2D Mater. 2019, 6, 2. [CrossRef]

86. Li, L.; Fu, L.; Ai, X.; Zhang, J.; Zhou, J. Design and fabrication of temperature-sensitive nanogels with controlled drug release properties for enhanced photothermal sterilization. Chemistry 2017, 23, 18180-18186. [CrossRef] [PubMed]

87. Kim, S.H.; Kang, E.B.; Jeong, C.J.; Sharker, S.M.; In, I.; Park, S.Y. Light controllable surface coating for effective photothermal killing of bacteria. ACS Appl Mater Interfaces 2015, 7, 15600-15606. [CrossRef]

88. Hsiao, C.-W.; Chen, H.-L.; Liao, Z.-X.; Sureshbabu, R.; Hsiao, H.-C.; Lin, S.-J.; Chang, Y.; Sung, H.-W. Effective photothermal killing of pathogenic bacteria by using spatially tunable colloidal gels with nano-localized heating sources. Adv. Funct. Mater. 2015, 25, 721-728. [CrossRef]

89. Liu, T.; Zhang, M.; Liu, W.; Zeng, X.; Song, X.; Yang, X.; Zhang, X.; Feng, J. Metal ion/tannic acid assembly as a versatile photothermal platform in engineering multimodal nanotheranostics for advanced applications. ACS Nano 2018, 12, 3917-3927. [CrossRef]

90. Basuki, J.S.; Qie, F.; Mulet, X.; Suryadinata, R.; Vashi, A.V.; Peng, Y.Y.; Li, L.; Hao, X.; Tan, T.; Hughes, T.C. Photo-modulated therapeutic protein release from a hydrogel depot using visible light. Angew. Chem. Int. Ed. Engl. 2017, 56, 966-971. [CrossRef]

91. Graham, S.; Marina, P.F.; Blencowe, A. Thermoresponsive polysaccharides and their thermoreversible physical hydrogel networks. Carbohydr. Polym. 2019, 207, 143-159. [CrossRef] [PubMed]

92. Deng, H.; Yu, Z.; Chen, S.; Fei, L.; Sha, Q.; Zhou, N.; Chen, Z.; Xu, C. Facile and eco-friendly fabrication of polysaccharides-based nanocomposite hydrogel for photothermal treatment of wound infection. Carbohydr. Polym. 2020, 230, 115565. [CrossRef] [PubMed]

93. Huang, W.C.; Tsai, P.J.; Chen, Y.C. Multifunctional $\mathrm{Fe}_{3} \mathrm{O}_{4} @ \mathrm{Au}$ nanoeggs as photothermal agents for selective killing of nosocomial and antibiotic-resistant bacteria. Small 2009, 5, 51-56. [CrossRef] [PubMed]

94. Qian, W.; Yan, C.; He, D.; Yu, X.; Yuan, L.; Liu, M.; Luo, G.; Deng, J. Ph-triggered charge-reversible of glycol chitosan conjugated carboxyl graphene for enhancing photothermal ablation of focal infection. Acta Biomater. 2018, 69, 256-264. [CrossRef]

95. Korupalli, C.; Huang, C.-C.; Lin, W.-C.; Pan, W.-Y.; Lin, P.-Y.; Wan, W.-L.; Li, M.-J.; Chang, Y.; Sung, H.-W. Acidity-triggered charge-convertible nanoparticles that can cause bacterium-specific aggregation in situ to enhance photothermal ablation of focal infection. Biomaterials 2017, 116, 1-9. [CrossRef]

96. Zhao, Y.-Q.; Sun, Y.; Zhang, Y.; Ding, X.; Zhao, N.; Yu, B.; Zhao, H.; Duan, S.; Xu, F.-J. Well-defined gold nanorod/polymer hybrid coating with inherent antifouling and photothermal bactericidal properties for treating an infected hernia. ACS Nano 2020, 14, 2265-2275. [CrossRef]

97. Banerjee, I.; Pangule, R.C.; Kane, R.S. Antifouling coatings: Recent developments in the design of surfaces that prevent fouling by proteins, bacteria, and marine organisms. Adv. Mater. 2011, 23, 690-718. [CrossRef] 
98. Kumar, A.; Alam, A.; Rani, M.; Ehtesham, N.Z.; Hasnain, S.E. Biofilms: Survival and defense strategy for pathogens. Int. J. Med. Microbiol. 2017, 307, 481-489. [CrossRef]

99. Keum, H.; Kim, J.Y.; Yu, B.; Yu, S.J.; Kim, J.; Jeon, H.; Lee, D.Y.; Im, S.G.; Jon, S. Prevention of bacterial colonization on catheters by a one-step coating process involving an antibiofouling polymer in water. ACS Appl. Mater. Interfaces 2017, 9, 19736-19745. [CrossRef]

100. Qing, G.; Zhao, X.; Gong, N.; Chen, J.; Li, X.; Gan, Y.; Wang, Y.; Zhang, Z.; Zhang, Y.; Guo, W.; et al. Thermo-responsive triple-function nanotransporter for efficient chemo-photothermal therapy of multidrugresistant bacterial infection. Nat. Commun. 2019, 10, 4336. [CrossRef]

101. Vigderman, L.; Khanal, B.P.; Zubarev, E.R. Functional gold nanorods: Synthesis, self-assembly, and sensing applications. Adv. Mater. 2012, 24, 4811-4841. [CrossRef] [PubMed]

102. Ding, Y.; Sun, Z.; Shi, R.; Cui, H.; Liu, Y.; Mao, H.; Wang, B.; Zhu, D.; Yan, F. Integrated endotoxin adsorption and antibacterial properties of cationic polyurethane foams for wound healing. ACS Appl. Mater. Interfaces 2018, 11, 2860-2869. [CrossRef] [PubMed]

103. Yuan, H.; Yu, B.; Fan, L.-H.; Wang, M.; Zhu, Y.; Ding, X.; Xu, F.-J. Multiple types of hydroxyl-rich cationic derivatives of PGMA for broad-spectrum antibacterial and antifouling coatings. Polym. Chem. 2016, 7, 5709-5718. [CrossRef]

104. Li, M.; Li, L.; Su, K.; Liu, X.; Zhang, T.; Liang, Y.; Jing, D.; Yang, X.; Zheng, D.; Cui, Z. Highly effective and noninvasive near-infrared eradication of a staphylococcus aureus biofilm on implants by a photoresponsive coating within $20 \mathrm{~min}$. Adv. Sci. 2019, 6, 1900599. [CrossRef]

105. Liu, X.; Huang, H.; Liu, G.; Zhou, W.; Chen, Y.; Jin, Q.; Ji, J. Multidentate zwitterionic chitosan oligosaccharide modified gold nanoparticles: Stability, biocompatibility and cell interactions. Nanoscale 2013, 5, 3982-3991. [CrossRef]

106. Manivasagan, P.; Khan, F.; Hoang, G.; Mondal, S.; Kim, H.; Doan, V.H.M.; Kim, Y.-M.; Oh, J. Thiol chitosanwrapped gold nanoshells for near-infrared laser-induced photothermal destruction of antibiotic-resistant bacteria. Carbohydr. Polym. 2019, 225, 115228. [CrossRef]

107. Zhou, Z.; Kong, B.; Yu, C.; Shi, X.; Wang, M.; Liu, W.; Sun, Y.; Zhang, Y.; Yang, H.; Yang, S. Tungsten oxide nanorods: An efficient nanoplatform for tumor CT imaging and photothermal therapy. Sci. Rep. 2014, 4, 3653. [CrossRef]

108. Xu, S.; Yong, L.; Wu, P. One-pot, green, rapid synthesis of flowerlike gold nanoparticles/reduced graphene oxide composite with regenerated silk fibroin as efficient oxygen reduction electrocatalysts. ACS Appl. Mater. Interfaces 2013, 5, 654-662. [CrossRef]

109. Zhang, C.; Zhao, K.; Bu, W.; Ni, D.; Liu, Y.; Feng, J.; Shi, J. Marriage of scintillator and semiconductor for synchronous radiotherapy and deep photodynamic therapy with diminished oxygen dependence. Angew. Chem. Int. Ed. 2015, 54, 1770-1774. [CrossRef]

110. Liu, Y.; Zhang, X.; Liu, Z.; Wang, L.; Luo, L.; Wang, M.; Wang, Q.; Gao, D. Gold nanoshell-based betulinic acid liposomes for synergistic chemo-photothermal therapy. Nanomedicine 2017, 13, 1891-1900. [CrossRef]

111. Rovati, D.; Albini, B.; Galinetto, P.; Grisoli, P.; Bassi, B.; Pallavicini, P.; Dacarro, G.; Taglietti, A. High stability thiol-coated gold nanostars monolayers with photo-thermal antibacterial activity and wettability control. Nanomaterials 2019, 9, 1288. [CrossRef] [PubMed]

112. Meeker, D.G.; Jenkins, S.V.; Miller, E.K.; Beenken, K.E.; Loughran, A.J.; Powless, A.; Muldoon, T.J.; Galanzha, E.I.; Zharov, V.P.; Smeltzer, M.S. Synergistic photothermal and antibiotic killing of biofilm-associated staphylococcus aureus using targeted antibiotic-loaded gold nanoconstructs. ACS Infect. Dis. 2016, 2, 241-250. [CrossRef] [PubMed]

113. Peng, R.; Luo, Y.; Cui, Q.; Wang, J.; Li, L. Near-infrared conjugated oligomer for effective killing of bacterial through combination of photodynamic and photothermal treatment. ACS Appl. Bio Mater. 2020, 3, 1305-1311. [CrossRef]

114. Mahmoud, N.N.; Alhusban, A.A.; Ali, J.I.; Al-Bakri, A.G.; Hamed, R.; Khalil, E.A. Preferential accumulation of phospholipid-peg and cholesterol-peg decorated gold nanorods into human skin layers and their photothermal-based antibacterial activity. Sci. Rep. 2019, 9, 5796. [CrossRef]

115. Huang, X.; Jain, P.K.; El-Sayed, I.H.; El-Sayed, M.A. Plasmonic photothermal therapy (pptt) using gold nanoparticles. Laser Med. Sci. 2007, 23, 217. [CrossRef]

116. Al-Bakri, A.G.; Mahmoud, N.N. Photothermal-induced antibacterial activity of gold nanorods loaded into polymeric hydrogel against pseudomonas aeruginosa biofilm. Molecules 2019, 24, 2661. [CrossRef] 
117. Ikuma, K.; Decho, A.W.; Lau, B.L. When nanoparticles meet biofilms—interactions guiding the environmental fate and accumulation of nanoparticles. Front. Microbiol. 2015, 6, 591. [CrossRef]

118. Rekhi, S.; Tempere, J.; Silvera, I.F. Temperature determination for nanosecond pulsed laser heating. Rev. Sci. Instrum. 2003, 74, 3820-3825. [CrossRef]

119. Watnick, P.; Kolter, R. Biofilm, city of microbes. J. Bacteriol. 2000, 182, 2675-2679. [CrossRef]

120. von Eiff, C.; Jansen, B.; Kohnen, W.; Becker, K. Infections associated with medical devices: Pathogenesis, management and prophylaxis. Drugs 2005, 65, 179-214. [CrossRef]

121. Vinh, D.C.; Embil, J.M. Device-related infections: A review. J. Long Term Eff. Med. Implant. 2005, 15, 467-488. [CrossRef] [PubMed]

122. Russell, A. Lethal effects of heat on bacterial physiology and structure. Sci. Prog. 2003, 86, 115-137. [CrossRef] [PubMed]

123. Wood, S.; Metcalf, D.; Devine, D.; Robinson, C. Erythrosine is a potential photosensitizer for the photodynamic therapy of oral plaque biofilms. J. Antimicrob. Chemother. 2006, 57, 680-684. [CrossRef] [PubMed]

124. Costerton, J.W.; Lewandowski, Z.; DeBeer, D.; Caldwell, D.; Korber, D.; James, G. Biofilms, the customized microniche. J. Bacteriol. 1994, 176, 2137-2142. [CrossRef]

125. Budimir, M.; Jijie, R.; Ye, R.; Barras, A.; Melinte, S.; Silhanek, A.; Markovic, Z.; Szunerits, S.; Boukherroub, R. Efficient capture and photothermal ablation of planktonic bacteria and biofilms using reduced graphene oxide-polyethyleneimine flexible nanoheaters. J. Mater. Chem. B 2019, 7, 2771-2781. [CrossRef]

126. Ye, M.Y.; Zhao, Z.H.; Hu, Z.F.; Liu, L.Q.; Ji, H.M.; Shen, Z.R.; Ma, T.Y. Od/2d heterojunctions of vanadate quantum dots/graphitic carbon nitride nanosheets for enhanced visible-light-driven photocatalysis. Angew. Chem. Int. Ed. 2017, 56, 8407-8411. [CrossRef]

(C) 2020 by the authors. Licensee MDPI, Basel, Switzerland. This article is an open access article distributed under the terms and conditions of the Creative Commons Attribution (CC BY) license (http://creativecommons.org/licenses/by/4.0/). 